\title{
Probabilistic Precipitation Anomalies Associated with ENSO
}

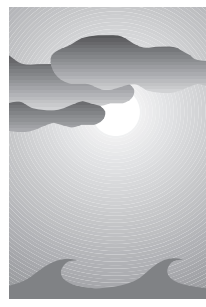

Simon J. Mason* and Lisa Goddard ${ }^{+}$

\begin{abstract}
Extreme phases of the El Niño-Southern Oscillation (ENSO) phenomenon have been blamed for precipitation anomalies in many areas of the world. In some areas the probability of above-normal precipitation may be increased during warm or cold events, while in others below-normal precipitation may be more likely. The percentages of times that seasonal precipitation over land areas was above, near, and below normal during the eight strongest El Niño and La Niña episodes are tabulated, and the significance levels of the posterior probabilities are calculated using the hypergeometric distribution. These frequencies may provide a useful starting point for probabilistic climate forecasts during strong ENSO events. Areas with significantly high or low frequencies or above- or below-normal precipitation are highlighted, and attempts are made to estimate the proportion of land areas with significant ENSO-related precipitation signals.

There is a danger of overstating the global impact of ENSO events because only about $20 \%-30 \%$ of land areas experience significantly increased probabilities of above- or below-normal seasonal precipitation during at least some part of the year. Since different areas are affected at different times of the year, the fraction of global land affected in any particular season is only about $15 \%-25 \%$. The danger of focusing on the impact of only warm-phase events is emphasized also: the global impact of La Niña seems to be at least as widespread as that of El Niño. Furthermore, there are a number of notable asymmetries in precipitation responses to El Niño and La Niña events. For many areas it should not be assumed that the typical climate anomaly of one ENSO extreme is likely to be the opposite of the other extreme. A high frequency of above-normal precipitation during strong El Niño conditions, for example, does not guarantee a high frequency of below-normal precipitation during La Niña events, or vice versa. On a global basis El Niño events are predominantly associated with below-normal seasonal precipitation over land, whereas La Niña events result in a wider extent of above-normal precipitation.
\end{abstract}

\section{Introduction}

El Niño-Southern Oscillation (ENSO) warm events are associated with climate extremes over many areas of the globe (Bradley et al. 1987; Ropelewski and Halpert 1987, 1989, 1996; Kiladis and Diaz 1989;

\footnotetext{
*Climate Research Division, Scripps Institution of Oceanography, University of California, San Diego, La Jolla, California.

+International Research Institute for Climate Prediction, LamontDoherty Earth Observatory, Columbia University, Palisades, New York.

Corresponding author address: Dr. Simon J. Mason, Scripps Institution of Oceanography, University of California, San Diego, Mail Code 0230, La Jolla, CA 92093-0230.

E-mail: simon@lacosta.ucsd.edu

In final form 6 October 2000.

(C) 2001 American Meteorological Society
}

Halpert and Ropelewski 1992). Because of the relatively high predictability of the ENSO phenomenon (Cane and Zebiak 1985; Cane et al. 1986; Latif et al. 1998; Neelin et al. 1998; Stockdale et al. 1998a,b), prior knowledge of the expected state of the equatorial Pacific Ocean provides a significant source of predictability of seasonal climate variability over much of the Tropics, and farther afield (Palmer and Anderson 1994). Knowing what typically has occurred during previous ENSO events gives some indication of what is likely to happen during a present or upcoming event. For many parts of the world this knowledge provides a better estimate of the probable future climate than the assumption that seasonal conditions will be the same as average.

A composite of climate anomalies observed during past ENSO events provides some useful information about typical ENSO impacts (e.g., Bradley et al. 
1987; Kiladis and van Loon 1988; Kiladis and Diaz 1989). However, using historical ENSO-related climate anomalies as simple forecasts of expected conditions is not straightforward. Even if the magnitude and structure of ENSO sea surface temperature anomalies were identical from one event to the next, the general problem of inherent unpredictability of the atmosphere would lead to differences in the climate anomalies observed during each event. The nonlinear interactions with sea surface temperature anomalies in the other oceans (e.g., Goddard and Graham 1999) and the existence of inter-El Niño differences (Hoerling and Kumar 1997) further compound the uncertainty in expected climate anomalies associated with El Niño and La Niña events. During the 1997-98 El Niño and 1998-99 La Niña a number of regions, for which climate variability is known to be well correlated to ENSO events, experienced conditions that could not be considered typical (Goddard et al. 1998; Kane 1999a). For example, the widespread anomalously dry conditions over southern Africa associated with the El Niño events of 1982-83 and 1991-92 (Mason and Jury 1997) did not recur during the 1997-98 rainfall season (Thiaw et al. 1999). Similarly, in Ecuador and northern Peru, where precipitation typically is above normal during El Niño and below normal during La Niña, the unusually wet conditions experienced during the 1997-98 El Niño persisted through the 1998-99 La Niña.

Correlation and regression constitute commonly used alternatives to composite analysis (sometimes called superposed epoch analysis). They describe the strength and form of the linear teleconnection between ENSO variability and global or regional climate anomalies. In some areas, however, the ENSO-climate relationship is asymmetric between El Niño and La Niña events. In many areas the relationships also have varied in strength from one epoch to the next (Ramage 1983; Pittock 1984; Ropelewski and Halpert 1986; Schonher and Nicholson 1989; Halpert and Ropelewski 1992; Mason and Mimmack 1992; Stone and Auliciems 1992; Nicholls et al. 1996; Hoerling et al. 1997; Livezey et al. 1997; Gershunov 1998; Gershunov and Barnett 1998; Mo and Higgins 1998; Montroy et al. 1998; Fontaine et al. 1999; Kane 1999b; Kruger 1999; Kumar et al. 1999; Navarra et al. 1999; Power et al. 1999; Rocha 1999; Torrence and Webster 1999). In addition, correlation coefficients can be sensitive to underlying assumptions about the probability distributions of the data and, so, are inappropriate for defining the strength of ENSO-precipitation signals, for example, in areas with highly skewed precipitation distributions.
Given the limitations of the composite and linear measures of ENSO influences for forecasting future impacts, it is of value to estimate the probabilities of climate anomalies conditional upon the phase of ENSO (Ropelewski and Halpert 1996). A simple approach is to use contingency tables. This approach can provide a measure for identifying the influence of an independent variable on the probability of a predefined climate event occurring. The contingency table is used to determine whether the events are more or less likely to occur given different values of the independent variable. For example, warm and cold ENSO episodes have been associated with extremes in global precipitation eigenmodes (Lau and Sheu 1991), in regional precipitation (Shukla and Paolina 1983; Parthasarathy et al. 1988; Barnett et al. 1991; Lau and Sheu 1991; Hutchinson 1992; Webster et al. 1998), and in annual numbers of hurricane days in the North Atlantic (Gray and Sheaffer 1991). The contingency table method was used by Ropelewski and Halpert $(1987,1989)$ to identify changes in median precipitation conditional upon the phase of the Southern Oscillation.

In this paper, the influence of extreme ENSO states on global precipitation anomalies is investigated using contingency tables. This paper extends the analyses of Ropelewski and Halpert $(1987,1989)$ to consider three categories rather than the two categories used in their analyses of station data. Thus precipitation anomalies that are only weakly positive or negative are considered "near normal" and are not counted in the climate impacts. The results provide useful indications of the global impacts of El Niño and La Niña events in probabilistic terms and using newly available high-resolution datasets. By using gridded and spatially interpolated precipitation data that provide complete coverage of global land areas, a first attempt can be made to estimate the proportion of the earth's land surface that has a significant ENSOrelated precipitation signal.

\section{Data and methods}

\section{a. Data}

Gridded monthly precipitation data at a resolution of $0.5^{\circ} \times 0.5^{\circ}$ were obtained from New et al. (1999, 2000). The almost 12000 stations represented in this gridded dataset were expanded from the original Climate Research Unit-Department of Energy data described in Eischeid et al. (1991), and developed by Hulme (1994) and the Climate Research Unit at the 
University of East Anglia. After extensive quality control the station data anomalies were averaged into $0.5^{\circ}$ grids and then interpolated using thin-plate splines. Data are available from the beginning of the century, but only the $45-y r$ period $1951-52$ to $1995-96$ has been considered in this paper because of diminished quality of both the gridded precipitation data and the sea surface temperature data, described below, prior to about 1950 . For each grid point seasonal precipitation totals were calculated and assigned to the belownormal, normal, or above-normal tercile. The analyses were repeated using the lower-resolution $\left(2.5^{\circ} \times 3.75^{\circ}\right)$ dataset of Hulme (1994) as a quality check on the results obtained by using the high-resolution data.

\section{b. Identification of ENSO-related climate impacts}

The historical impacts of El Niño and La Niña events on climate can be illustrated effectively by calculating the observed percentage of times that seasonal precipitation or temperature has been in the upper, middle, and lower climatological terciles during ENSO extremes (Mason et al. 1999). A 3-month mean Niño-3.4 index was calculated by averaging Kaplan et al.'s (1998) sea surface temperature anomalies over the central equatorial Pacific Ocean $\left(5^{\circ} \mathrm{N}-5^{\circ} \mathrm{S}, 170^{\circ}-\right.$ $120^{\circ} \mathrm{W}$ ), and the warmest eight El Niño events between 1951-52 and 1995-96 were identified for each season. The selected El Niño years are indicated in Table 1a, which shows the warmest 11 events. By selecting the eight warmest events in each season the Niño-3.4 index exceeds one standard deviation in all cases except for June-August 1992. Similarly, the eight coldest La Niña events were selected and are listed in Table 1b. Again the selection of eight events ensures that in most cases the Niño-3.4 index exceeds one standard deviation. Although there are some differences in the sea surface temperature threshold used between seasons and between ENSO phases, the standardized thresholds are reasonably similar. In addition, because of the small sample sizes and highly discrete form of the distributions used in the significance tests, as discussed below, the constant number of selected cases facilitates comparison of results. However, to test the robustness of the results, all analyses were repeated using only the 5 strongest ENSO events and using the 11 strongest events. The strongest 5 events correspond with a minimum Niño-3.4 anomaly of about $0.6^{\circ} \mathrm{C}$, while the strongest 11 events correspond with a minimum anomaly of about $0.35^{\circ} \mathrm{C}$. Changing the number of selected ENSO events between 5, 8, and 11 effected only incidental differences in the results, and so results are presented only for the strongest eight events. Where notable differences do occur, they are mentioned.

The numbers of times that the observed precipitation anomalies during these warm- and cold-event years were in each tercile were tabulated for each grid point. These frequencies give some indication of the likelihood of observing a climate anomaly in each of the categories during El Niño and La Niña events, respectively. Areas experiencing a "dry season" (defined as a 3-month period in which, on average, the precipitation total is less than $15 \%$ of the annual total and less than $50 \mathrm{~mm}$ ) and areas in which the seasonal precipitation total was zero in at least one-third of the years were masked. Antarctica has been excluded from the analysis because of a lack of observational data, although there probably is a detectable precipitation signal there (Bromwich et al. 2000).

\section{c. Calculation of significance levels}

The significance of the number of times that the observed precipitation or temperature anomalies during ENSO extreme events were above or below some predefined threshold can be calculated using contingency table theory. From a total of $n$ years, of which $b$ are "dry," and from which $r$ years are selected at random (the $r$ strongest El Niño years, e.g.), let the number of dry years that are selected, denoted by $X$, be equal to $x$ [where $0 \leq x \leq \min (r, b)$ ]. This information can be represented in a $2 \times 2$ contingency table, as shown in Table 2, or extended to a three-category problem, as shown in Table 3. Assuming there are a total of $r$ El Niño years and that $x$ of them are dry, then the significance is defined as the probability of selecting $x$ or more dry years in a random sample of $r$ years. This probability is equivalent to the right tail area of the hypergeometric distribution (Agresti 1990, 1996) and is given by

$$
p_{x}(X \geq x)=H(x ; r, b, n)=\sum_{k=x}^{\min (r, b)} \frac{\left(\begin{array}{l}
b \\
k
\end{array}\right)\left(\begin{array}{l}
n-b \\
r-k
\end{array}\right)}{\left(\begin{array}{l}
n \\
r
\end{array}\right)} .
$$

The test for significance defined by Eq. (1) is known as Fisher's exact test (Fisher 1935, 1970; Irwin 1935) (appendix A). In our case, where $n=45, b=15$, and $r=8$, five selected events is a significantly high number beyond the $90 \%$ level of confidence, six events is significant beyond the $95 \%$ level, and seven or more events is significant beyond the $99 \%$ level. Zero is a significantly low number of selected events beyond the 
TABLE 1. The 11 strongest (a) El Niño and (b) La Niña episodes over the period 1951-52 to 1995-96 during each 3-month season as measured by the Niño-3.4 index. The standard deviation $(\sigma)$ of the index is given. The second and third columns indicate the Niño3.4 sea surface temperature anomaly (SSTA) in ${ }^{\circ} \mathrm{C}$, and in standardized units $\left(\mid \sigma_{\text {rel }}\right)$. Average anomalies and standardized anomalies are shown for the strongest 5,8 , and 11 events.

(a)

\begin{tabular}{|c|c|c|c|c|c|c|c|c|c|c|c|}
\hline \multicolumn{3}{|c|}{$\begin{array}{c}\text { Dec-Jan-Feb } \\
\left(\sigma=0.87^{\circ} \mathrm{C}\right)\end{array}$} & \multicolumn{3}{|c|}{$\begin{array}{c}\text { Mar-Apr-May } \\
\left(\sigma=0.54^{\circ} \mathrm{C}\right)\end{array}$} & \multicolumn{3}{|c|}{$\begin{array}{c}\text { Jun-Jul-Aug } \\
\left(\sigma=0.57^{\circ} \mathrm{C}\right)\end{array}$} & \multicolumn{3}{|c|}{$\begin{array}{c}\text { Sep-Oct-Nov } \\
\left(\sigma=0^{\circ} 3^{\circ} \mathrm{C}\right)\end{array}$} \\
\hline Year & SSTA & $|\sigma|_{\text {rel }}$ & Year & SSTA & $|\sigma|_{\text {rel }}$ & Year & SSTA & $|\sigma|_{\text {rel }}$ & Year & SSTA & $|\sigma|_{\text {rel }}$ \\
\hline $1982-83$ & 1.92 & 2.21 & 1992 & 1.20 & 2.22 & 1987 & 1.15 & 2.02 & 1982 & 1.63 & 1.96 \\
\hline $1957-58$ & 1.49 & 1.71 & 1983 & 1.19 & 2.20 & 1972 & 1.02 & 1.79 & 1972 & 1.52 & 1.83 \\
\hline $1972-73$ & 1.48 & 1.70 & 1987 & 0.93 & 1.72 & 1991 & 1.02 & 1.79 & 1987 & 1.45 & 1.75 \\
\hline 1991-92 & 1.44 & 1.66 & 1958 & 0.78 & 1.44 & 1965 & 0.94 & 1.65 & 1965 & 1.32 & 1.59 \\
\hline $1965-66$ & 1.20 & 1.38 & 1969 & 0.77 & 1.43 & 1982 & 0.88 & 1.54 & 1991 & 1.06 & 1.28 \\
\hline 1994-95 & 1.08 & 1.24 & 1993 & 0.69 & 1.28 & 1957 & 0.70 & 1.23 & 1986 & 1.05 & 1.27 \\
\hline $1986-87$ & 1.06 & 1.22 & 1966 & 0.63 & 1.17 & 1994 & 0.59 & 1.04 & 1994 & 1.00 & 1.20 \\
\hline $1968-69$ & 1.04 & 1.20 & 1991 & 0.58 & 1.07 & 1992 & 0.55 & 0.96 & 1957 & 0.83 & 1.00 \\
\hline $1987-88$ & 0.83 & 0.95 & 1995 & 0.54 & 1.00 & 1958 & 0.50 & 0.88 & 1963 & 0.70 & 0.84 \\
\hline 1990-91 & 0.74 & 0.85 & 1994 & 0.47 & 0.87 & 1963 & 0.47 & 0.82 & 1976 & 0.75 & 0.90 \\
\hline 1969-70 & 0.71 & 0.82 & 1972 & 0.44 & 0.81 & 1969 & 0.43 & 0.75 & 1969 & 0.73 & 0.88 \\
\hline Avg 5 & 1.51 & 1.73 & Avg 5 & 0.97 & 1.80 & Avg 5 & 1.00 & 1.76 & Avg 5 & 1.40 & 1.68 \\
\hline Avg 8 & 1.34 & 1.54 & Avg 8 & 0.85 & 1.57 & Avg 8 & 0.86 & 1.50 & Avg 8 & 1.23 & 1.48 \\
\hline Avg 11 & 1.18 & 1.36 & Avg 11 & 0.75 & 1.38 & Avg 11 & 0.75 & 1.32 & Avg 11 & 1.09 & 1.32 \\
\hline
\end{tabular}

95\% level of confidence. Further discussions on the significance levels used in this paper are presented in appendix B.

When calculating more than one significance test, such as for different seasons or spatial grid points, the calculated significance level normally should be adjusted to account for multiplicity, using the bonferroni inequality if the tests are independent (Katz 1988; Brown and Katz 1991; Katz and Brown 1991). If the tests are not independent, because of spatial correlation for example, it would be necessary to resort to Monte Carlo methods to estimate field significance (Livezey and Chen 1983). Field significance tests were not conducted in this paper because the aim is to identify where the ENSO-related climate signal is locally significant, not to demonstrate that an ENSO signal exists. On the strength of considerable earlier research, it was assumed a priori that the ENSO phenomenon does have an impact on climate around the globe. Multiplicity problems do arise, however, when estimating the spatial extent of the ENSO signature. These issues are addressed below and in appendix B.

\section{d. Assumptions}

The accuracy of the significance tests is dependent on the validity of assumptions very similar to those 
TABle 1. Continued.

(b)

\begin{tabular}{|c|c|c|c|c|c|c|c|c|c|c|c|}
\hline \multicolumn{3}{|c|}{$\begin{array}{c}\text { Dec-Jan-Feb } \\
\left(\sigma=0.87^{\circ} \mathrm{C}\right)\end{array}$} & \multicolumn{3}{|c|}{$\begin{array}{c}\text { Mar-Apr-May } \\
\left(\sigma=0.54^{\circ} \mathrm{C}\right)\end{array}$} & \multicolumn{3}{|c|}{$\begin{array}{c}\text { Jun-Jul-Aug } \\
\left(\sigma=0.57^{\circ} \mathrm{C}\right)\end{array}$} & \multicolumn{3}{|c|}{$\begin{array}{c}\text { Sep-Oct-Nov } \\
\left(\sigma=\mathbf{0 . 8 3}^{\circ} \mathrm{C}\right)\end{array}$} \\
\hline Year & SSTA & $|\sigma|_{\text {rel }}$ & Year & SSTA & $|\sigma|_{\text {rel }}$ & Year & SSTA & $|\sigma|_{\text {rel }}$ & Year & SSTA & $|\sigma|_{\text {rel }}$ \\
\hline $1973-74$ & -1.66 & 1.91 & 1974 & -0.84 & 1.56 & 1975 & -1.07 & 1.88 & 1955 & -1.71 & 2.06 \\
\hline $1970-71$ & -1.51 & 1.74 & 1971 & -0.83 & 1.54 & 1988 & -1.02 & 1.79 & 1975 & -1.35 & 1.63 \\
\hline $1975-76$ & -1.44 & 1.66 & 1955 & -0.83 & 1.54 & 1973 & -0.81 & 1.42 & 1973 & -1.29 & 1.55 \\
\hline $1988-89$ & -1.35 & 1.55 & 1989 & -0.73 & 1.35 & 1955 & -0.75 & 1.32 & 1988 & -1.21 & 1.46 \\
\hline $1955-56$ & -1.02 & 1.17 & 1975 & -0.59 & 1.09 & 1956 & -0.69 & 1.21 & 1970 & -1.11 & 1.34 \\
\hline $1954-55$ & -0.99 & 1.14 & 1956 & -0.54 & 1.00 & 1964 & -0.68 & 1.19 & 1964 & -1.01 & 1.22 \\
\hline $1984-85$ & -0.71 & 0.82 & 1976 & -0.50 & 0.93 & 1954 & -0.67 & 1.18 & 1954 & -0.85 & 1.02 \\
\hline $1964-65$ & -0.71 & 0.82 & 1964 & -0.46 & 0.85 & 1970 & -0.57 & 1.00 & 1971 & -0.77 & 0.93 \\
\hline $1962-63$ & -0.62 & 0.71 & 1985 & -0.43 & 0.80 & 1971 & -0.60 & 1.05 & 1974 & -0.69 & 0.83 \\
\hline $1971-72$ & -0.51 & 0.59 & 1968 & -0.36 & 0.67 & 1974 & -0.45 & 0.79 & 1956 & -0.69 & 0.83 \\
\hline $1967-68$ & -0.48 & 0.55 & 1967 & -0.35 & 0.65 & 1959 & -0.35 & 0.61 & 1962 & -0.47 & 0.57 \\
\hline Avg 5 & -1.40 & 1.60 & Avg 5 & -0.76 & 1.41 & Avg 5 & -0.87 & 1.52 & Avg 5 & -1.33 & 1.61 \\
\hline Avg 8 & -1.17 & 1.35 & Avg 8 & -0.67 & 1.23 & Avg 8 & -0.78 & 1.37 & Avg 8 & -1.16 & 1.40 \\
\hline Avg 11 & -1.00 & 1.15 & Avg 11 & -0.59 & 1.09 & Avg 11 & -0.70 & 1.22 & Avg 11 & -1.01 & 1.22 \\
\hline
\end{tabular}

that are required for a Monte Carlo test for significance, in which the observational data are repeatedly scrambled, or the selected years are repeatedly redefined (Livezey and Chen 1983). In both cases it is assumed that the observation in one year is independent of the observations in another year, which can be tested using autoregressive methods (Wilks 1995). In practice this assumption of independence will be invalid if there is a trend or significant low-frequency variability in the data. If the selected years are reasonably well distributed throughout the period of interest, the effects of autocorrelation and trend are probably not too serious, and the calculated significance levels will err on the conservative side. If the selected years are clustered, the effects will be more severe, and significance
TABLE 2. Two-by-two contingency table for verification of a binary forecast system.

\begin{tabular}{lccc}
\hline & \multicolumn{3}{c}{ El Niño years } \\
\cline { 2 - 4 } Observations & Yes & No & Total \\
\hline Dry & $x$ & $b-x$ & $b$ \\
Not dry & $r-x$ & $n-r-b+x$ & $n-b$ \\
Total & $r$ & $n-r$ & $n$ \\
\hline
\end{tabular}


is likely to be overestimated. By purposely clustering the selected years, tests for climate change can be conducted. For example, significantly high frequencies of events in the last few years of a series may provide evidence for trends (Wigley and Jones 1987).

\section{e. Estimating the area of ENSO signals}

Percentages of total land area not experiencing a dry season or dry conditions (as defined in section $2 b$ ) and that experienced significantly high frequencies of precipitation in either the above- or below-normal tercile category were calculated. Grid areas were weighted by the cosine of the latitude. In calculating
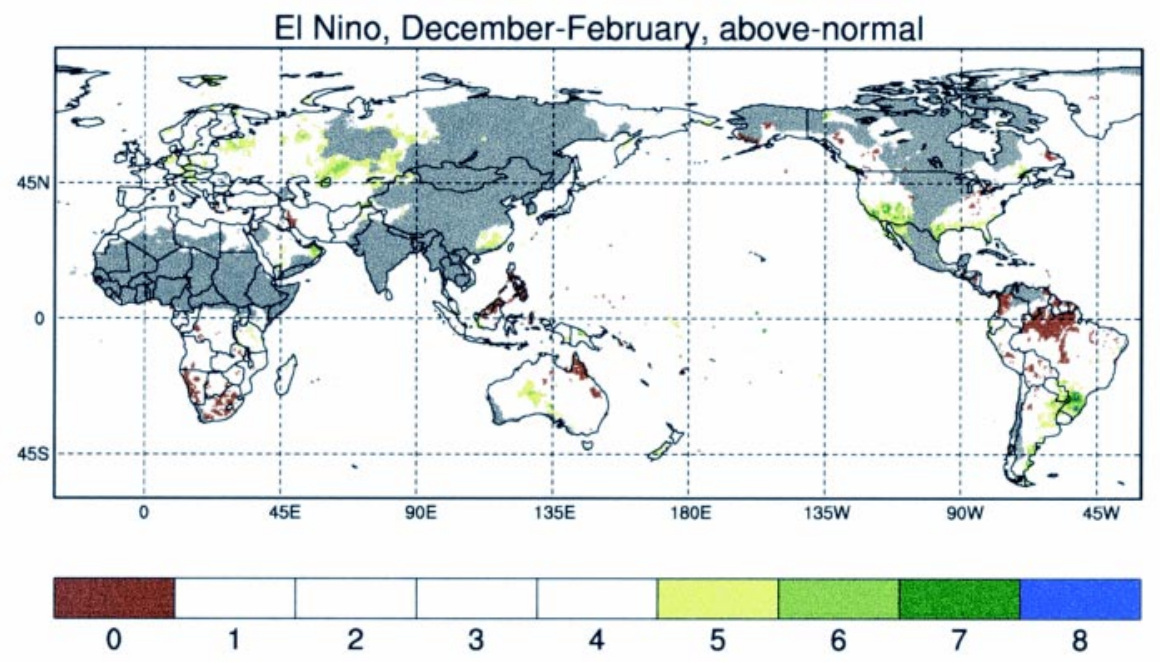

Frequency

\begin{tabular}{|l|l|l|l|l|l|l|l|l|l|}
0 & 1 & 2 & 3 & 4 & 5 & 6 & 7 & 8 \\
\hline
\end{tabular}

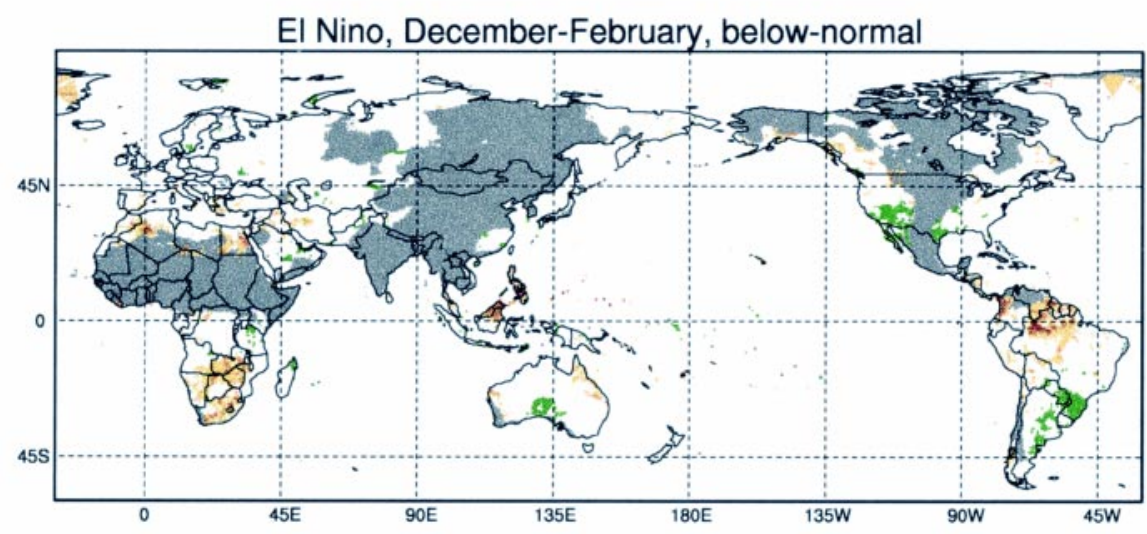

FIG. 1. Frequencies of (top) above- and (bottom) below-normal Dec-Feb precipitation during the eight strongest El Niño events from 1951-52 to 1995-96, defined using the Niño-3.4 index (1957-58, 1965-66, 1968-69, 1972-73, 1986-87, 1982-83, 1991-92, 1994-95). Frequencies are shown only where they are significantly high or low at a $90 \%$ level of confidence. these areas an $85 \%$ confidence level has been used to identify grid points with significantly high frequencies of above- or below-normal precipitation. The estimated areas with ENSO impacts should therefore be considered upper limits, and may be overestimated by $10 \%$ or more, as discussed in appendix B.

All area estimates were compared against the coarser-resolution Hulme (1994) dataset. These results are in close agreement with those from the New et al. $(1999,2000)$ dataset, but suggest that areas with observed above- or below-normal precipitation in more than half of the selected El Niño or La Niña events may be underestimated by at most $5 \%$. However, apart from the smoothing of detected signals over larger grid areas at a coarser resolution, the Hulme (1994) dataset also provides a disproportionate weight to the Pacific islands and coastal areas, since it is assumed that any grid containing land is entirely land. It is therefore likely that the Hulme (1994) dataset may lead to slight overestimates of the area of ENSO signals, and so the area estimates from the New et al. $(1999,2000)$ dataset are considered more realistic.

Since the areas affected by ENSO change from season to season, a more meaningful indication of the global extent of ENSO teleconnections may be obtained by calculating total areas with ENSO-related seasonal climate anomalies at any time of year. Area estimates were made for all twelve 3-month seasons and all areas with a significant signal in at least one of the seasons were identified. Because of problems of multiplicity when performing tests for more than one season and for the thousands of grid points (Katz 1988; Brown and Katz 1991; Katz and Brown 1991; Wilks 1995), only areas with above- or belownormal rainfall in at least $75 \%$ of the eight El Niño or La Niña events were counted. The test 
therefore considers only areas that have had a significantly high frequency of either aboveor below-normal precipitation at the $95 \%$ level of confidence (see appendix B).

\section{Precipitation anomalies associated with El Niño}

Areas where there has been a significantly high or low number of years with above- and below-normal seasonal precipitation during the eight strongest El Niño episodes since 1951-52 are shown in Figs. 1-4. Results for the near-normal category are not shown because of an absence of spatially coherent signals, although there are few areas where the probability of near-normal precipitation increases significantly during ENSO events. Areas of significant decreases in the probability of near-normal precipitation are almost invariably reflected by significant increases in one of the other two categories. The main features are described in the following sections, and further details and references are
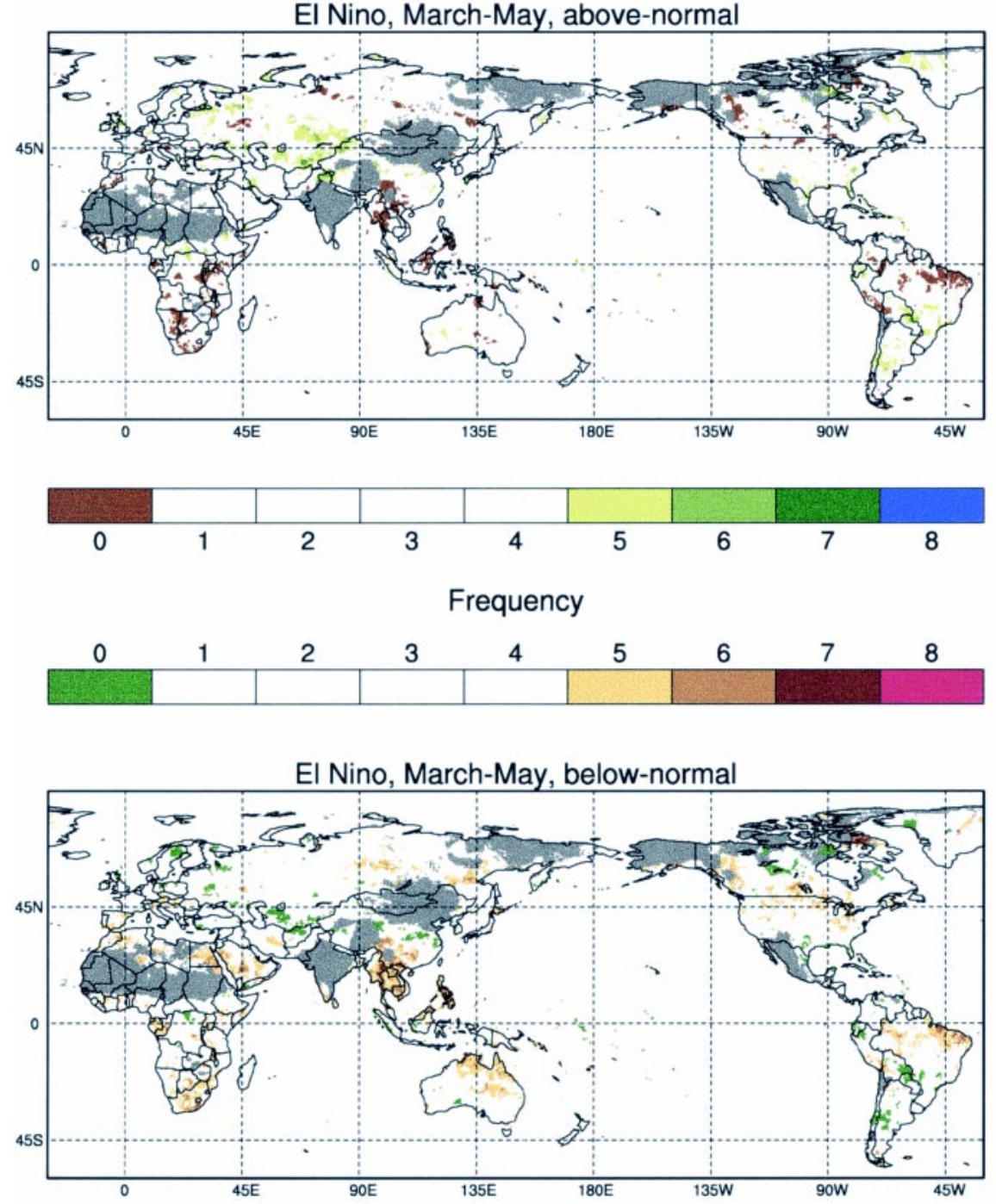

FIG. 2. Frequencies of (top) above- and (bottom) below-normal Mar-May precipitation during the eight strongest El Niño events from 1951 to 1995 , defined using the Niño-3.4 index $(1958,1966,1969,1983,1987,1991,1992,1993)$. Frequencies are shown only where they are significantly high or low at a $90 \%$ level of confidence.

reserved for appendix $\mathrm{C}$.

\section{a. December-February}

There are surprisingly few areas where the frequency of above-normal December-February precipitation has been significantly high during El Niño events (Fig. 1a). Of all nondry land areas excluding Antarctica, only about $8 \%$ experienced a significantly high frequency (in more than half the cases) of above-normal precipitation, which is only slightly more than would be expected by chance (6.8\%). Despite the weak global impact, there are some regions where El Niño has been associated with significantly high frequencies of above-average precipitation. The signal appears to have been most reliable

TABLE 3. Three-by-two contingency table for verification of a binary forecast system.

\begin{tabular}{lccc}
\hline \hline & \multicolumn{3}{c}{ El Niño years } \\
\cline { 2 - 4 } Observations & Yes & No & Total \\
\hline Dry & $x$ & $b-x$ & $b$ \\
Not dry, not wet & $r-x-y$ & $n-r-b-a+x+y$ & $n-b-a$ \\
Wet & $y$ & $a-y$ & $a$ \\
Total & $r$ & $n-r$ & $n$ \\
\hline
\end{tabular}


El Nino, June-August, above-normal
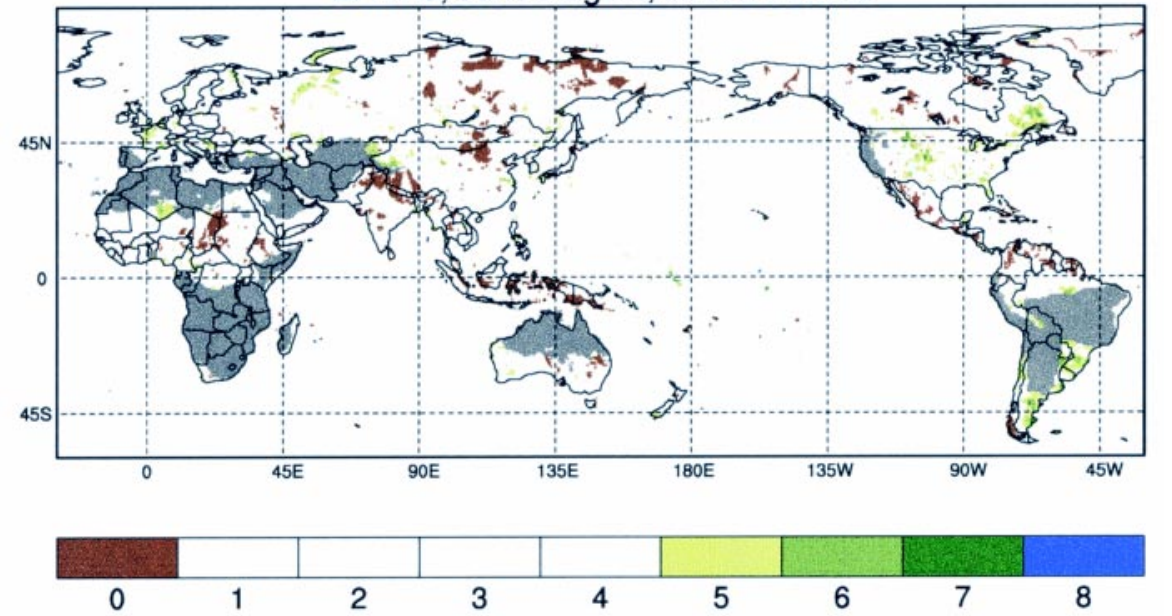

Frequency

\begin{tabular}{|l|l|l|l|l|l|l|l|l|l|}
0 & 1 & 2 & 3 & 4 & 5 & 6 & 7 & 8 \\
\hline
\end{tabular}

El Nino, June-August, below-normal

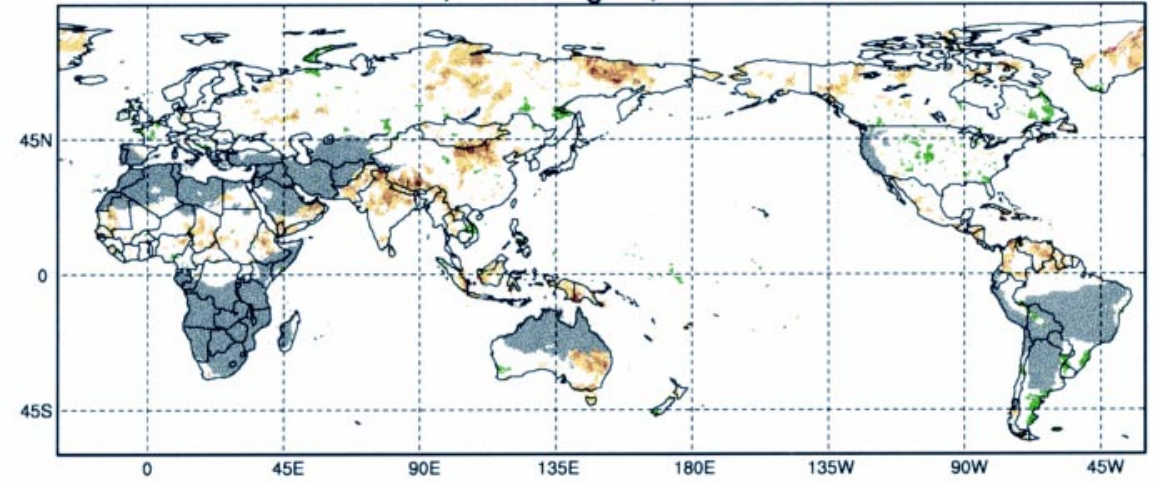

FIG. 3. Frequencies of (top) above- and (bottom) below-normal Jun-Aug precipitation during the eight strongest El Niño events from 1951 to 1995, defined using the Niño-3.4 index $(1957,1965,1972,1982,1987,1991,1992,1994)$. Frequencies are shown only where they are significantly high or low at a $90 \%$ level of confidence.

over southern Brazil where $75 \%$ or more of the eight strongest El Niño episodes were accompanied by above-average precipitation, and none of them were accompanied by below-normal precipitation (Fig. 1b). Over the United States-Mexico border region, the signal has been widespread, but exceeds $75 \%$ only in localized areas, partly as a reflection of interdecadal variations in the strength of the association (McCabe and Dettinger 1999). A strong signal has been evident also over some of the central near-equatorial Pacific islands and seems to have peaked in strength near the Christmas Islands where above-normal precipitation was experienced in seven of the eight strongest El Niño events.
El Niño is associated with areas with high probabilities of below-normal DecemberFebruary precipitation (Fig. 1b) rather than above-normal precipitation. Significantly high frequencies of below-normal precipitation occurred over about $11 \%$ of non-dry areas, which is almost twice the area expected by chance. Over $3 \%$ of land areas experienced below-normal precipitation in more than $75 \%$ of the cases, which is over three times the area expected by chance (1.1\%). Below-normal precipitation occurred during El Niño most frequently over central Indonesia, the southern Philippines, and parts of Micronesia and the Marshall Islands, but was also widespread over northern South America, southern Africa, and parts of northern Africa. Below-normal precipitation over land during El Niño conditions in December-February was therefore much more widespread than above-normal precipitation. In total, about $19 \%$ of nondry land areas have experienced significant precipitation impacts during December-February.

\section{b. March-May}

Although probabilities of anomalous March-May precipitation conditions during El Niño events (Fig. 2) weakened in most areas compared to December-February (Fig. 1), with the notable exception of the Philippines, total land areas experiencing anomalous precipitation changed only minimally. There was a small expansion of the area experiencing below-normal precipitation to more than $12 \%$, again almost twice the area expected by chance. Below-normal precipitation at this time of year was widespread throughout southeastern Asia, northern Australia, parts of Africa and the Middle East, and along the north coast of Brazil. The expansion of the area experiencing below-normal precipitation was more than offset by a fairly substantial contraction of areas of above-normal precipitation. 
The signal for above-normal precipitation was reasonably strong over parts of central Russia and the former Soviet states, but less than $6 \%$ of land areas experienced above-normal precipitation in more than half of the cases, and less than $1 \%$ experienced above-normal precipitation in $75 \%$ of the cases or more. In both instances these areas are less than would be expected by chance. The March-May El Niño-related signal therefore is predominantly one of high probabilities of below-normal precipitation over global land areas (Fig. 1b) (Bradley et al. 1987). Areas that have experienced below-normal precipitation were more than twice as widespread as areas experiencing above-normal precipitation. Considering both above- and below-normal precipitation, about $18 \%$ of nondry land areas are significantly affected by El Niño in MarchMay.

Despite a substantial weakening in the average Niño-3.4 anomaly (Table 1a) between December-February $\left(1.34^{\circ} \mathrm{C}\right)$ and March-May $\left(0.85^{\circ} \mathrm{C}\right)$ there is no observed decrease in land areas experiencing significantly high frequencies of either above- or below-normal precipitation. The difference between the average standardized Niño-3.4 anomalies of December-February (1.55) and March-May (1.57) is negligible, and so the atmosphere must remain highly sensitive to the weakening positive sea surface temperature after the mature phase of an El Niño event, which most of the selected events represent (Table 1a).

\section{c. June-August}

Areas of significantly high frequencies of abovenormal precipitation during El Niño events in boreal summer (Jun-Aug) (Fig. 3) again have been constrained to only a few areas. Only about $5 \%$ of land areas ex- perienced high frequencies of above-normal precipitation in more than half of the cases. Most of these areas are concentrated in the Americas. Again, belownormal precipitation has been widespread, with over $14 \%$ of nondry land areas experiencing below-normal conditions in more than half of the cases, which is more than twice the area expected by chance. Similarly, just over $4 \%$ of areas experienced below-normal precipitation in at least $75 \%$ of the cases, four times the area expected by chance. Areas with strong belownormal signals include eastern Australia, Indonesia, and parts of eastern and southern Asia. Thus, again, approximately $19 \%$ of nondry land areas observed significantly high probabilities of either above- or below- 
normal precipitation during El Niño events in June-August.

For this season, most of the selected warm events represent the growth phase of an El Niño (Table 1a). The average Niño-3.4 anomaly $\left(0.86^{\circ} \mathrm{C}\right)$ is about the same as for March-May $\left(0.85^{\circ} \mathrm{C}\right)$, and the standardized anomalies are very similar also ( $1.50 \mathrm{com}$ pared with 1.57). Given that the occurrence of below-normal precipitation during these early stages of developing El Niño events is widespread, the importance of early warnings of developing warm events is highlighted.

\section{d. September-November}

During September-November (Fig. 4), the widespread high frequencies of below-normal precipitation persisted, and strengthened in areas such as eastern Australia and Indonesia. The total nondry land areas that experienced below-normal precipitation in more than half of the cases was over $13 \%$, which is little changed from the previous season. Areas where belownormal precipitation occurred in all eight El Niño years reached their maximum extent (just under $0.1 \%$ ) in this season, but are largely confined to the western Pacific. Similarly, areas where above-normal precipitation occurred in all eight years reached their maximum extent $(0.06 \%)$ in September-November and are focused in the central Pacific. Over continental areas, high frequencies of widespread above-normal precipitation were confined largely to the Middle East, parts of east Africa, and the United States. Almost $9 \%$ of land areas experienced above-normal precipitation during more than half of the El Niño episodes.

In September-November the extent of the El Niñorelated precipitation signal appears to reach a maximum, even though the El Niño itself typically reaches maturity only in the following season. The average Niño-3.4 index was $1.23^{\circ} \mathrm{C}$, which is a 10 th of a degree of confidence.
La Nina, December-February, above-normal

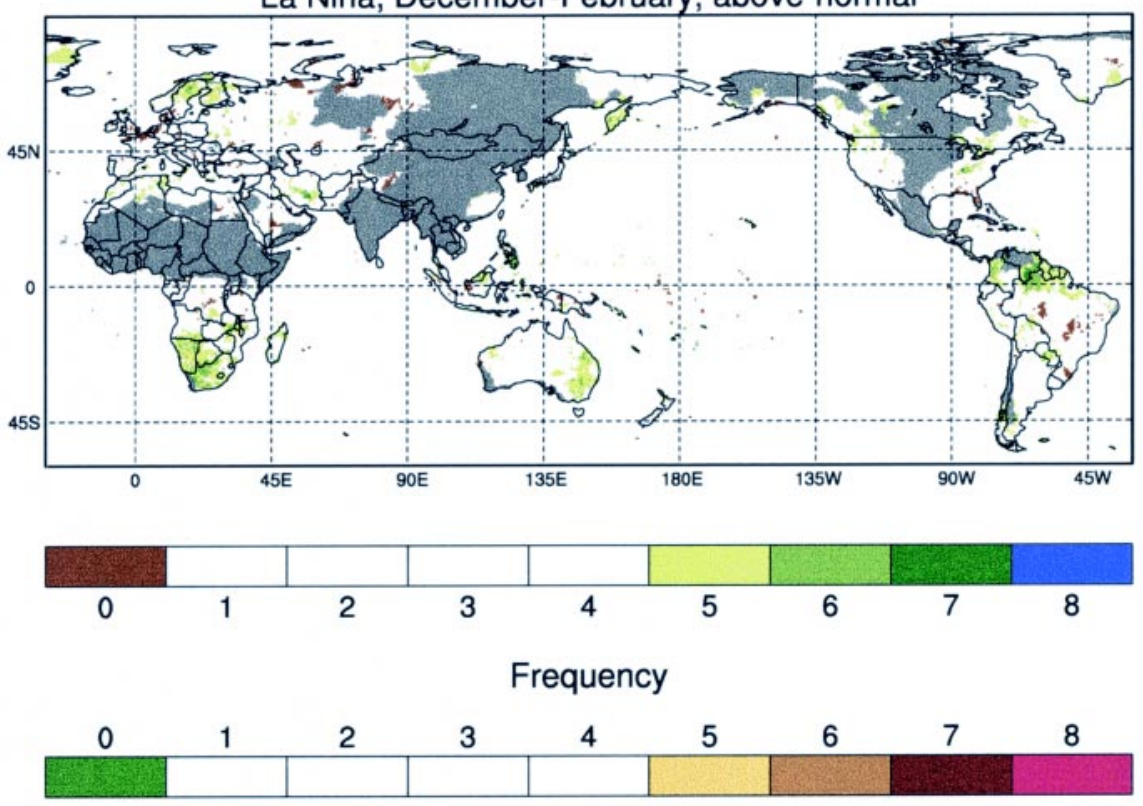

La Nina, December-February, below-normal

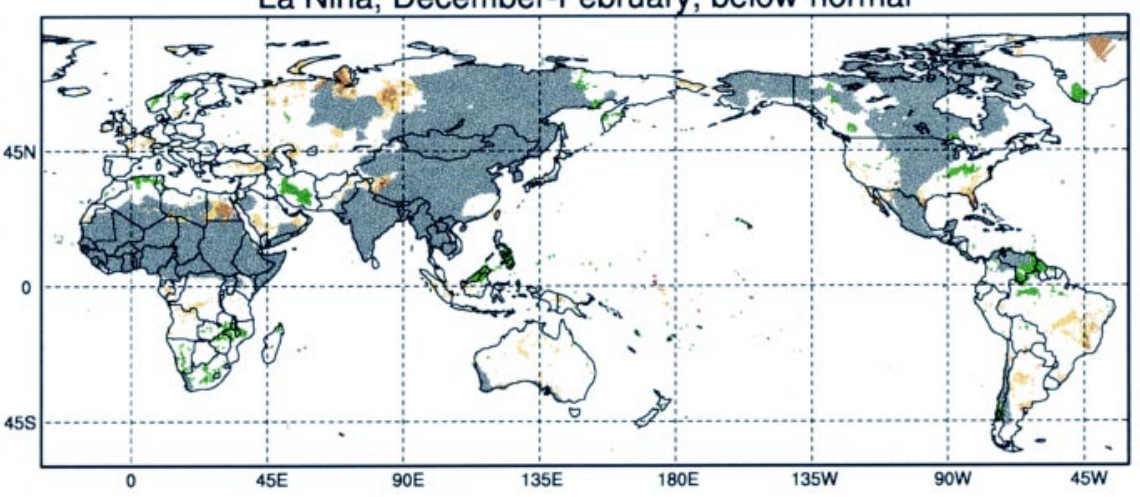

FIG. 5. Frequencies of (top) above- and (bottom) below-normal Dec-Feb precipitation (the 89). 89). Frequencies are shown only where they are significantly high or low at a $90 \%$ level

(celsius) cooler than the December-February average (Table 1a), but the averaged standardized index, at 1.49 , is similar to that for the other three seasons. The area where below-normal precipitation occurred in more than half of the cases was slightly less than during June-August, but areas where below-normal precipitation was experienced in over $85 \%$ of the El Niño cases were most widespread in September-November. Similarly, the area where the frequency of abovenormal precipitation was significantly high reached a maximum in this season (about $8 \%$ or $9 \%$ ). This amounts to a total of about $22 \%$ of land areas during El Niño associated with above- or below-normal precipitation in September-November. 


\section{Precipitation anomalies associated with La Niña}

Some symmetry exists between the precipitation anomalies associated with La Niña and El Niño episodes (cf. Figs. 1-4 with 5-8). In this section, only the important exceptions to the symmetry are highlighted.

\section{a. December-February}

In the United States, La Niña appears to have had a weaker influence on precipitation than El Niño in the southwest of the country, but a stronger influence in the southeast (Fig. 5b). Similar differences between the strength of the El Niño and La Niña signals are found for southeastern South America, parts of southern Africa, and for southeastern China. As opposed to El Niño, which was associated mainly with below-normal precipitation over land areas, the areas with high frequencies of belownormal precipitation (less than $8 \%$ ) during La Niña events were less than the areas of abovenormal precipitation (about $12 \%$ ). Thus approximately $20 \%$ of nondry land areas exhibited precipitation impacts during La Niña events in DecemberFebruary.

\section{b. March-May}

During March-May, there is again reasonable symmetry between the El Niño (Fig. 2) and La Niña signals (Fig. 6). Noteworthy exceptions are Australia, where precipitation impacts were more robust during La Niña, and northeastern Brazil and southeastern Asia, where the La Niña signal was weaker. Overall, the impacts of La Niña were experienced over approximately the same area $(19 \%)$ as those of El Niño (18\%), but the preference for above-normal precipitation characteristic of La Niña in the DecemberFebruary season is no longer evident. The areas with high fre- quencies of above- and below-normal precipitation during La Niña events were about $10 \%$ in each case. The total area of significant anomalous precipitation in either direction was only marginally less than in the other seasons, even though the absolute sea surface temperature anomalies were considerably weaker than during September-February (Table 1b). If only the strongest five cold events are considered, there are few areas outside of Australia that indicate a widespread impact of La Niña on precipitation during March-May.

\section{c. June-August}

The preference for above-normal precipitation to occur during cold extremes of the ENSO phenomenon

\section{La Nina, March-May, above-normal}
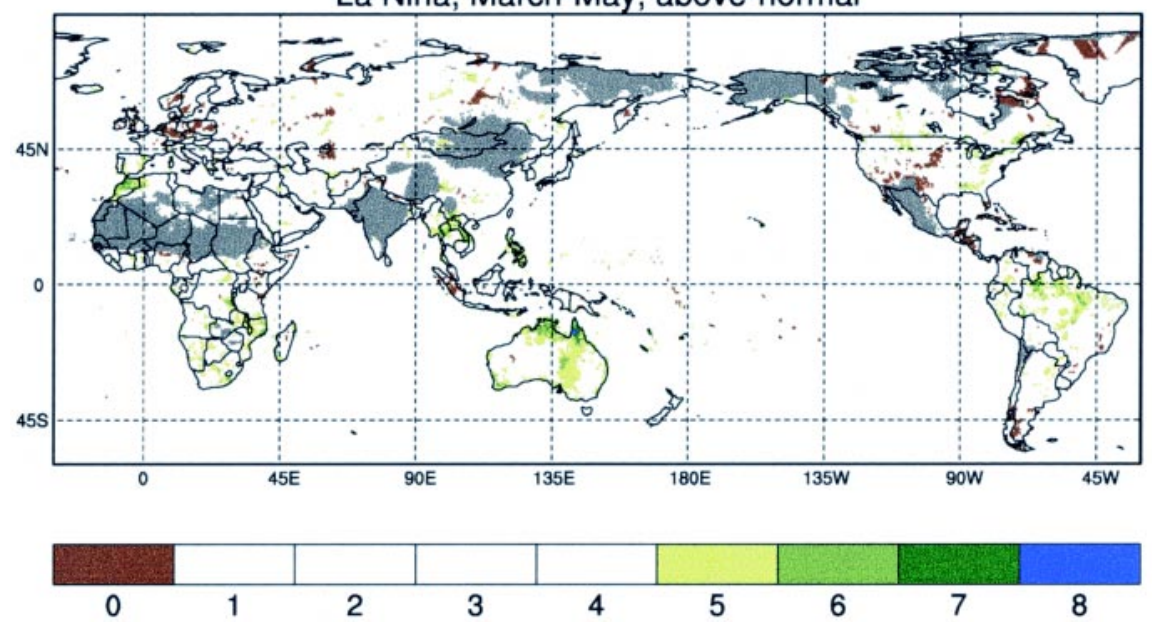

Frequency

\begin{tabular}{|l|l|l|l|l|l|l|l|l|}
\hline 0 & 1 & 2 & 3 & 4 & 5 & 7 & 8 \\
\hline
\end{tabular}

La Nina, March-May, below-normal

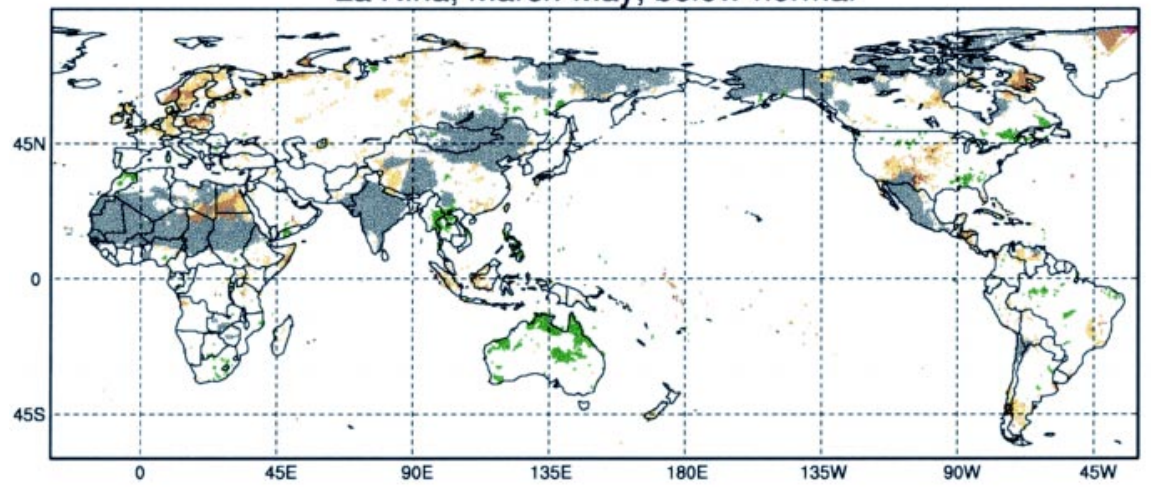

FIG. 6. Frequencies of (top) above- and (bottom) below-normal Mar-May precipitation during the eight strongest La Niña events from 1951 to 1995 , defined using the Niño-3.4 index $(1950,1955,1956,1971,1974,1975,1976,1989)$. Frequencies are shown only where they are significantly high or low at a $90 \%$ level of confidence. 
in December-February is reestablished during July-August. Above-normal precipitation occurred much more frequently than below normal throughout the continental Tropics, and occurred over more than $12 \%$ of all nondry land areas, compared to about $8 \%$ for below normal.

\section{d. September-November}

Again there is reasonable symmetry between the El Niño (Fig. 4) and La Niña signals (Fig. 8) during SeptemberNovember, although there are some notable exceptions. The most marked asymmetry is probably that the strength of the below-normal signal over southeastern South America was much stronger during La Niña than the opposite signal was during El Niño. In northeastern Argentina $100 \%$ of the selected La Niña events were associated with below-normal precipitation. The impact of El Niño events over this region apparently is delayed until the December-February season when a high frequency of above-normal seasonal precipitation has been observed (Fig. 1a). In total about $12 \%$ of nondry areas experienced high frequencies of above-normal precipitation.

High frequencies of belownormal precipitation are evident over western Saudi Arabia, the Kyrgyzstan area, and the central nearequatorial Pacific islands so that $0.28 \%$ of all nondry land areas had below-normal precipitation in all the selected La Niña events. The area that experienced equally high frequencies of above-normal rainfall also reached a maximum extent $(0.32 \%)$ at this time of year. These areas were concentrated mainly in the Indonesia-northern Australia region. As was shown for El Niño, therefore, the global impact of La Niña on seasonal precipitation appears to reach a maximum in September-November. The area with high frequencies of below-normal precipitation during La Niña events reached a maximum (almost 13\%) in this season.
La Nina, June-August, above-normal

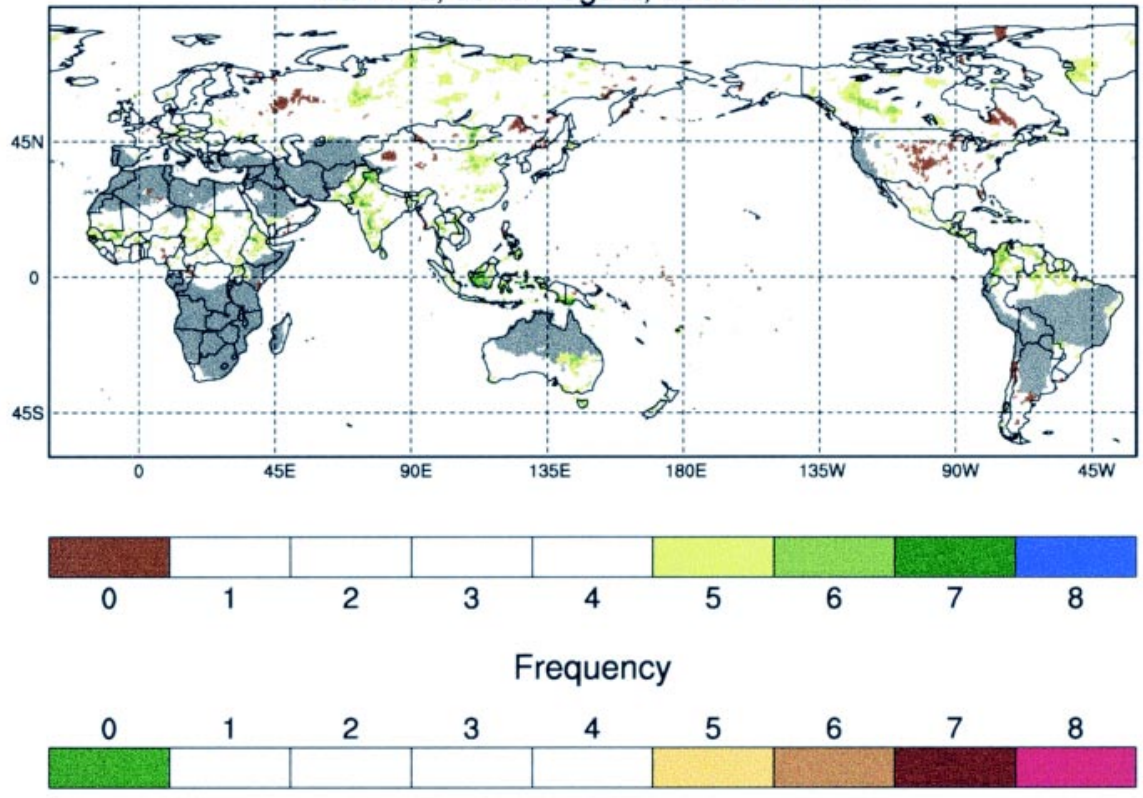

La Nina, June-August, below-normal

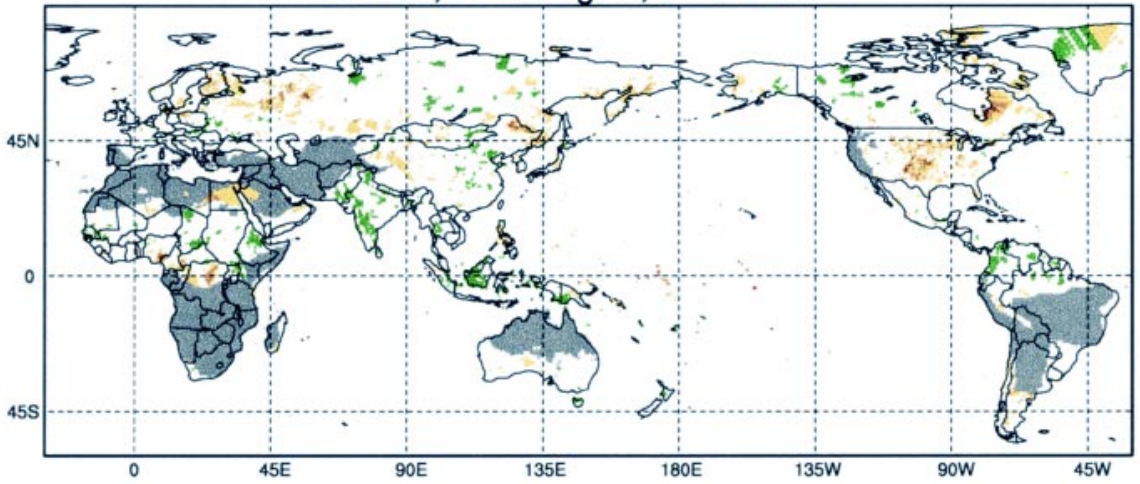

FIG. 7. Frequencies of (top) above- and (bottom) below-normal Jun-Aug precipitation index $(1950,1954,1955,1956,1964,1973,1975,1988)$. Frequencies are shown only where they are significantly high or low at a $90 \%$ level of confidence.
The total area experiencing high frequencies of above- or below-normal precipitation in SeptemberNovember is about $25 \%$ of nondry land areas. As for El Niño, this area is at a maximum during SeptemberNovember, even though ENSO events typically reach maturity only in the following season. However, the average Niño-3.4 index during the eight strongest La Niña events was $-1.16^{\circ} \mathrm{C}$, which is indistinguishable from the December-February average of $1.17^{\circ} \mathrm{C}$ (Table $1 \mathrm{~b}$ ), and the averaged standardized index, at -1.40 , is slightly stronger than in the other seasons. 


\section{Discussion and conclusions}

Previous analyses of precipitation anomalies associated with El Niño and La Niña events have indicated the global nature of ENSO-related teleconnections (Bradley et al. 1987; Ropelewski and Halpert 1987, 1989, 1996; Kiladis and Diaz 1989). In this paper a newly available high-resolution dataset (New et al. 1999, 2000) was used to extend the results of earlier analyses. Areas with significantly high frequencies of either below- or above- normal precipitation during ENSO events were identified, and were indicated in Figs. 1-8. Only data after 1951 were considered to ensure that data quality is maximized, and only the strongest ENSO events were investigated. An attempt has been made to obtain estimates of the percentage of global land areas with a strong ENSO-related precipitation signal.

The results confirm that climate anomalies associated with El Niño and La Niña events do occur on a global basis, but suggest that caution should be exercized to not exaggerate the local significance or the global coverage of the ENSO influence. During the eight strongest El Niño and eight strongest La Niña episodes over the period 1951-52 to 1995-96, precipitation anomalies beyond either the above- or below-normal terciles occurred in more than half of the selected ENSO events over no more than about $15 \%-25 \%$ of land areas in any 3 -month season. The spatial coverage decreases to about $5 \%$ when considering precipitation anomalies that occurred in at least two-thirds of the cases, and to an average of only about $0.1 \%$ for anomalies in all eight cases. The limited extent of these areas highlights the event-to-event variability in observed precipitation anomalies during ENSO episodes, and indicates a definite need to emphasize the probabilistic nature of the climate re- sponse rather than focusing on a composite response to past ENSO events (Ropelewski and Halpert 1996).

The areas affected by ENSO change from season to season. The total area experiencing ENSO-related climate anomalies in at least one of the twelve 3-month seasons gives a more meaningful indication of the global extent of ENSO teleconnections, but the exact significance levels of this are difficult to determine because of multiplicity problems. However, areas with high frequencies of anomalous seasonal precipitation at some time of year that are locally significant beyond the $95 \%$ level of confidence constitute only about 20 $30 \%$ of total land areas. Results using the 11 strongest El Niño or La Niña events suggest that seasonal pre-
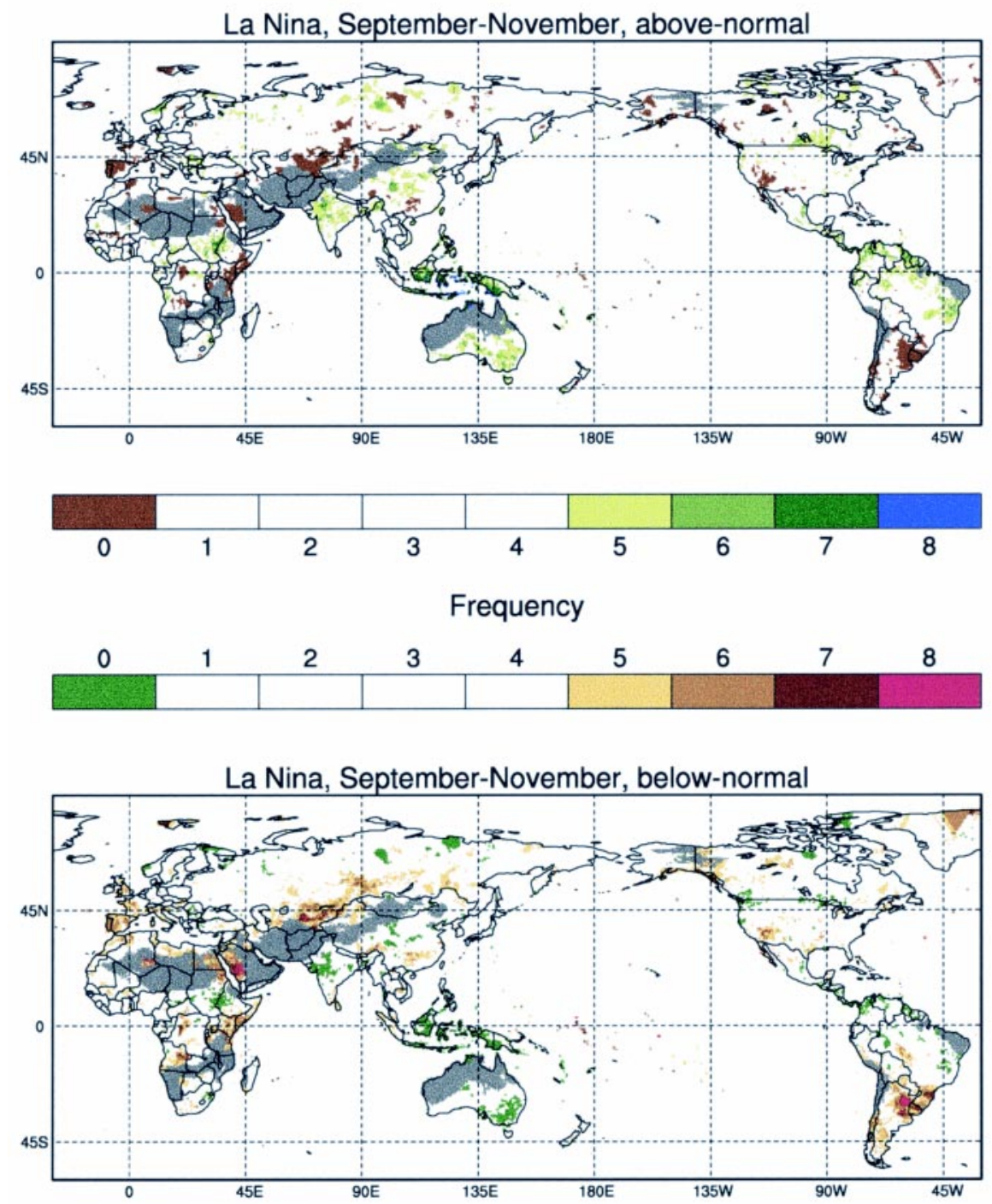

FIG. 8. Frequencies of (top) above- and (bottom) below-normal Sep-Nov precipitation during the eight strongest El Niño events from 1951 to 1995 , defined using the Niño-3.4 index $(1950,1954,1955,1964,1970,1973,1975,1988)$. Frequencies are shown only where they are significantly high or low at a $90 \%$ level of confidence. 
cipitation over as much as $30 \%-45 \%$ of land areas may be affected at some time in the year. It should be emphasized that the difference in these estimates is because of a sensitivity to unavoidable changes in the significance level used, and not because of a sensitivity to the number of selected ENSO events per se. Estimates of the spatial extent of ENSO impacts are therefore sensitive to the strength of the signal that is considered, but what can be concluded is that areas with strong ENSO-related seasonal precipitation signals are restricted in extent, but areas with a weak signal are much more widespread (see appendix B for a more detailed discussion).

The danger of overemphasizing the climate response to strong ENSO events is particularly apparent in the case of El Niño, which is usually the ENSO extreme that receives greatest attention. The results presented in this paper and supported elsewhere (e.g., Hoerling et al. 1997; Vega et al. 1998) suggest that the impact of La Niña is at least as widespread as that of El Niño. It is estimated that La Niña affects precipitation over about 5\%-15\% more of the land surface than El Niño. Given that the magnitude of the SST anomalies defining the La Niña events considered here was weaker than those of El Niño, the extent of the La Niña-related climate impacts is probably a result of the more localized anomalous tropical convection relative to that during El Niño events.

It is difficult to identify a clear seasonal cycle in the proportion of land areas that have experienced a strong ENSO-related precipitation signal. The magnitude of SST anomalies associated with ENSO events does differ between seasons, but the differences in the standardized anomalies are small. This suggests that the relative magnitude of the anomalous SST is what matters for the seasonal climate. There are, however, some indications that the spatial extent of the precipitation signal is greatest in the September-November season. For El Niño, the precipitation signal is predominantly below-normal precipitation over land areas year-round (Bradley et al. 1987). For La Niña, some seasonality exists in the precipitation signal with more regions experiencing above-normal precipitation during June-August and December-February. It should be emphasized that these results apply only to land areas, and do not imply a global increase or decrease in precipitation in either ENSO extreme. The impact of ENSO events on precipitation over much of the central Pacific is sampled by only a few islands and so the spatial extent of precipitation anomalies in this region are vastly underrepresented.
Where ENSO events do have a significant impact on precipitation anomalies, it seems reasonable to use historical relative frequencies, such as those shown in Figs. 1-8, to derive probabilistic estimates of a precipitation anomaly for a season in which an ENSO event is anticipated. During the 1997-98 El Niño and the 1998-99 La Niña, for example, the composite frequencies of ENSO impacts were often used to suggest the likely outcomes for the following months, and were an important input to the International Research Institute for Climate Prediction "net assessments" (Mason et al. 1999). However, obtaining a forecast from contingency tables of historical impacts is complicated. If the probabilities obtained using a contingency table approach are to be used in a forecasting environment, the table should be constructed so that the probabilities are contingent upon forecasts of ENSO events rather than on observed events. Given that there is still much uncertainty involved in forecasting ENSO events operationally (Barnston et al. 1999; Landsea and Knaff 2000), probability estimates obtained from Figs. 1-8 are likely to be overconfident. There is additional uncertainty arising from the modulating influence of sea surface temperatures in other ocean areas. Providing reliable estimates of forecast probabilities therefore has to consider uncertainties in the evolution of global sea temperatures, as well as errors in estimating the historical ENSO impacts.

Acknowledgments. This paper was funded by a grant/ cooperative agreement from the National Oceanic and Atmospheric Administration (NOAA). The views expressed herein are those of the authors and do not necessarily reflect the views of NOAA or any of its subagencies. Discussions with C. F. Ropelewski, S. E. Zebiak, and N. E. Graham are gratefully acknowledged.

\section{Appendix A: Calculation of the hypergeometric equation}

With only a slight loss of accuracy because of floating point errors, hypergeometric probabilities can be calculated using

$$
\begin{aligned}
h(x ; r, b, n)=\exp & {\left[\sum_{i=b-x+1}^{b} \ln i+\sum_{i=n-b-r+x+1}^{n-b} \ln i+\sum_{i=r-x+1}^{r} \ln i\right.} \\
& \left.-\sum_{i=r}^{r} \ln i-\sum_{i=1}^{x} \ln i-\sum_{i=n-r+1}^{n} \ln \right]
\end{aligned}
$$

where $b$ is the number of cases of $n$ with the characteristics of interest and $x$ is the number of $r$ selected 
cases with the characteristic. The right-tail area [Eq. (1)] can then be calculated using

$$
p_{x}(X \geq x)=H(x ; r, b, n)=\sum_{k=x}^{\min (r, b)} h(k ; r, b, n) .
$$

Further rounding errors may be minimized by reversing the summation in Eq. (A2) so that $k=\min (r, b)$ is calculated first, and $k=x$ is calculated last. For greater accuracy, the problem can be reformulated using prime number factorizations to minimize the number of computations (Wu 1993), but for most climatological applications, Eqs. (A1) and (A2) should be sufficiently accurate.

\section{Appendix B: Confidence levels}

Because of the discrete form of the hypergeometric distribution, the values of $p_{X}$ become highly discrete with small samples. Significance tests for these distributions therefore can become conservative. For example, given the parameters used in this paper for the hypergeometric distribution $(n=45, b=15$, and $r=8$ ), at least five below-normal cases have to be selected for below-normal precipitation to be significantly frequent at the $90 \%$ level of confidence. However, there is only a $6.8 \%$ probability of selecting five or more cases (in a one-tailed test). Similarly, at least six cases have to be selected at the $95 \%$ level of confidence, but there is only a $1.1 \%$ probability of selecting six or more cases. The probability of selecting seven or more cases is less than $0.1 \%$. Significantly low frequencies are indicated in addition, but mainly for ease of comparing the El Niño and La Niña signals. There is a $2.7 \%$ probability of selecting no cases.

Since there is interest in high frequencies of both above- and below-normal precipitation, a two-tailed test is more appropriate. A test conducted with a $90 \%$ level of confidence then becomes highly conservative. At least six or more below-normal or above-normal cases would have to be selected to be significant at a $90 \%$ level of confidence, even though there is only a $2.2 \%$ probability of selecting six or more of one of the two cases. The next step is to adopt an approximately $85 \%$ level of confidence and to count areas with at least five below-normal or five above-normal cases; there is a $13.6 \%$ probability of selecting five or more of one of the two cases. In Figs. 1-8, areas with above- or below-normal precipitation in more than half of the eight strongest El Niño or La Niña years are indicated, and thus an $85 \%$ level of confidence has been used. Since an $85 \%$ confidence level is liberal, the percentage areas with significant ENSO impacts in any of the four seasons should be considered upper limits. An approximately $95 \%$ level of confidence can be used if the 11 strongest El Niño or La Niña events are considered. The areas with significant ENSO impacts are then estimated to be about $11 \%$ or $12 \%$ less than the quoted areas.

These significance tests make no correction for problems of multiplicity, which should be considered acute given the thousands of grid points over which the test is conducted. The problem of multiplicity becomes even more serious when estimating the total area with an ENSO-related precipitation signal at some time of the year. For this reason, the $85 \%$ confidence level used to mask areas in Figs. 1-8 was considered too liberal for identifying areas with ENSO signals in each of the 12 seasons. As discussed above, the next step is to count only those areas with six or more of the eight selected events having below-normal or above-normal precipitation, which is equivalent to having a confidence level of about $98 \%$. This level of confidence has been used. The results are compared with those obtained by counting those areas with 7 or more of the 11 selected events having above- or below-normal precipitation. There is a $4.0 \%$ probability of selecting seven or more cases. The confidence level is then reduced from about $98 \%$ to about $96 \%$, and indicates an increase in the area affected by about $10 \%-15 \%$. Conversely, the estimated area decreases dramatically if a slightly stricter confidence level is selected. The implication is that areas with strong ENSO-related seasonal precipitation signals are restricted in extent, but areas with a weak signal are widespread.

\section{Appendix C: Areas with significant ENSO-related precipitation anomalies}

Brief descriptions are provided of the extent of ENSO-related precipitation anomalies in each of the four seasons considered. The interested reader is referred to the cited references for more details.

\section{a. December-February}

Noteworthy areas where there has been a significantly high frequency of above-normal seasonal precipitation for December-February during El Niño 
events and that do not typically experience a dry season at this time of year include the following: Kiribati and the northern parts of French Polynesia and the Cook Islands (He and Barnston 1996); the southwestern and southeastern United States (Livezey et al. 1997; Montroy 1997; Mo and Higgins 1998; Montroy et al. 1998; Masutani and Leetmaa 1999; Minnich et al. 2000); southern Brazil and neighboring parts of Paraguay and Argentina (Wagner 1987; Grimm et al. 1998, 2000; Lucero 1998; Montecinos et al. 2000); southeastern China (Gong and Wang 1999; Wang et al. 2000); and parts of central Russia. Over Europe and the Middle East changes in storm tracks are thought to effect small changes in the probability of abovenormal winter precipitation in some areas (Fraedrich 1994; Rodo et al. 1997; Price et al. 1998; Kadioglu et al. 1999). Below-normal precipitation was prevalent over much of northern South America; central Indonesia, the southern Philippines, parts of Australia, Micronesia, and the Marshall Islands, extending southeastward to the southern Cook Islands (Fig. 1a) (Quinn et al. 1978; Allan 1991; Alory and Delcroix 1999); and parts of southern Africa (Mason and Jury 1997).

There are some notable asymmetries in the precipitation signals between warm and cold ENSO phases. In the United States, below-normal precipitation was more frequent in the southeast during La Niña than was above-normal precipitation during El Niño (Livezey et al. 1997). Other areas in which December-February precipitation appears to have been more strongly affected during La Niña episodes than during El Niño episodes include central eastern Brazil, southern Africa, eastern Australia, and parts of Europe (Fraedrich 1994; Davies et al. 1997). Over southern Africa, the asymmetry was notably strong when only the strongest five events were selected: above-normal precipitation occurred during all five La Niña events over large areas of South Africa and Namibia, whereas, a signal in the five strongest El Niño events was barely detectable. In some places, such as the southwestern United States (Livezey et al. 1997; Gershunov 1998) and southeastern South America, the signal during El Niño events was stronger.

\section{b. March-May}

The strong signals of above-normal DecemberFebruary precipitation over the United States-Mexico border region and over southern Brazil during El Niño events weakened considerably during March-May (Fig. 2a). Similarly, in northern South America, high frequencies of below-normal precipitation north of the equator weakened considerably (Xavier et al. 1995) but redeveloped over northeastern Brazil (Fig. 2b), although the influence of the tropical Atlantic or rainfall here may be more important (Ward and Folland 1991; Moron et al. 1995; Enfield 1996; Kane 1997, 1999b; Uvo et al. 1998; Fontaine et al. 1999; Nobre and Cavalcanti 1999). An equally strong change occurred over southeastern Asia, the Philippines, and islands farther east. During December-February, a strong signal of below-normal precipitation was evident over the Philippines, Palau, and Micronesia (Fig. 1b), but appeared to shift westward in MarchMay while weakening over Micronesia and developing over southeastern Asia. Signals over Australia strengthened a little, but remained weak.

In other areas, the signal was little changed in March-May compared to December-February. Over southern Africa, high frequencies of below-normal precipitation persisted, but with some weakening over Zambia and Zimbabwe (Fig. 2b), suggesting that an early end to the southern African rainfall seasons is likely during El Niño events (Waylen and Henworth 1996; Mason and Tyson 1999). Elsewhere in Africa, drier than normal conditions persisted in the Mediterranean states, but a below-normal similar signal is evident for La Niña (Fig. 6b) and so may be spurious. In northeastern Europe areas of significantly high frequencies of above-normal precipitation remained patchy (Fraedrich 1994; Rodo et al. 1999; van Oldenborgh et al. 2000). The stronger signal in the Kazakhstan area shifted southward reaching into northern India.

Changes in the areas with significant La Niñarelated climate anomalies between DecemberFebruary and March-May are broadly consistent with those of El Niño. Only the most noteworthy features are highlighted here. The most notable change is the development of high probabilities of above-normal precipitation over a large part of northern and easterncentral Australia (Fig. 6a), which developed more strongly than the signal for below-normal conditions during El Niño. In contrast, above-normal precipitation over southeastern Asia during the selected La Niña cases was not as frequent as below-normal during the eight strongest El Niño years. Apart from the persistence of strong signals over many of the tropical Pacific islands, signals elsewhere were relatively weak.

\section{c. June-August}

In the central equatorial Pacific over Nauru and Kiribati, above-normal precipitation conditions oc- 
curred frequently during El Niño events, but were not experienced at all over parts of Indonesia and Papua New Guines, Fiji, Tonga, and the southern Cook Islands (Fig. 3a). The frequent occurrence of belownormal conditions extended also over eastern Australia, suggesting that the impact of El Niño in this area is strongest during the developing stages rather than mature stages of a warm event (Fig. 3b). The strongest widespread El Niño-related signal over continental areas occurred over Pakistan and northern India, and extending eastward over Tibet. Here belownormal conditions occurred frequently. The impact on the Asian monsoon was strong, despite the importance of land surface characteristics in determining interannual rainfall variability (Hahn and Shukla 1976; Kawamura 1998; Webster et al. 1998; Ferranti and Molteni 1999; Kumar et al. 1999; Corti et al. 2000). There were no strong coherent signals over Africa during June-August: important rainfall does occur in the Sahelian belt, but the influence of the tropical Atlantic Ocean modulates the ENSO signal here significantly (Semazzi et al. 1988; Lamb and Peppler 1992; Moron et al. 1995; Janicot et al. 1998; Ward 1998; Fontaine et al. 1999).

There were weak, but significant, tendencies for above-normal precipitation to occur over the central parts of the United States (Bunkers et al. 1996; Livezey et al. 1997; Montroy et al. 1998), which results from variability in the strength and position of the uppertropospheric monsoon anticyclone, and may involve local sea surface temperature and precipitation feedback processes (Higgins et al. 1998). Above-normal precipitation likewise was evident over Quebec, and in parts of South America south of the equator. North of the equator, and over the Caribbean and parts of central America (Waylen et al. 1996), the widespread occurrence of below-normal precipitation at this time of year are evident.

The impact of La Niña events (Fig. 7) showed clear symmetry with that of El Niño during June-August, and so is not discussed further.

\section{d. September-November}

During September-November, the highest frequencies of above-normal precipitation during El Niño events occurred over the near-equatorial Pacific islands east of about $165^{\circ} \mathrm{E}$ (Fig. 4a). Similarly high probabilities of below-normal precipitation occurred during La Niña events in the same areas (Fig. 8a). The ENSO signal in precipitation was not much weaker, but of the opposite sign, over parts of Indonesia, Papua
New Guinea, the Solomon Islands, Vanuatu, New Caledonia, Fiji, and much of eastern Australia. During September-November, the strength of both the El Niño- and La Niña-related precipitation anomalies appear to reach a maximum, even though the associated sea surface temperature anomalies typically continue to develop well into the December-February season.

Over continental areas, the Middle East had high frequencies of above-normal precipitation during the selected El Niño events, indicating a high probability of a good start to the rainfall season (Nazemosadat and Gordery 2000). The signal seems to be displaced during the La Niña events, where high frequencies of below-normal precipitation occurred in the vicinity of the Red Sea, and also over Kyrgyzstan and surrounding areas.

Farther southeast, there is evidence that the late rains of the Indian monsoon were frequently poor (good) (Fig. 4b) during El Niño (La Niña). In Africa, the Short Rains of Kenya and neighboring areas were frequently above normal during El Niño events (Farmer 1988; Beltrando and Camberlin 1993; Mutai et al. 1998), but the signal changes sign over western and central Ethiopia and the southern half of Sudan, where the September-November season can contribute late-season rainfall. The opposite signals are evident for La Niña (Fig. 8). Over South America El Niño-related signals for September-November precipitation were not strong, but below-normal precipitation occurred very frequently over northeastern Argentina and neighboring areas during La Niña (Fig. 8b). In North America the El Niño impact seems to have been stronger than that of La Niña: over much of the central and western United States, including Alaska (Livezey et al. 1997), above-normal rainfall was fairly widespread, and below-normal rainfall was not observed in many of these areas (Fig. 4b).

\section{References}

Agresti, A., 1990: Categorical Data Analysis. John Wiley, 558 pp. _ 1996: An Introduction to Categorical Data Analysis. John Wiley, $290 \mathrm{pp}$.

Allan, R. J., 1991: Australasia. Teleconnections Linking Worldwide Climate Anomalies: Scientific Basis and Societal Impact, M. H. Glantz, R. W. Katz, and N. Nicholls, Eds., Cambridge University Press, 73-120.

Alory, G., and T. Delcroix, 1999: Climatic variability in the vicinity of Wallis, Futuna, and Samoa islands (13 degrees-15 degrees S, 180 degrees-170 degrees W). Oceanol. Acta, 22, 249-263. 
Barnett, T. P., L. Dümenil, U. Schlese, E. Roeckner, and M. Latif, 1991: The Asian snow cover-monsoon-ENSO connection. Teleconnections Linking Worldwide Climate Anomalies: Scientific Basis and Societal Impact, M. H. Glantz, R. W. Katz, and N. Nicholls, Eds., Cambridge University Press, 191-225.

Barnston, A. G., M. H. Glantz, and Y. He, 1999: Predictive skill of statistical and dynamical climate models in forecasts of SST during the 1997-98 El Niño episodes and the 1998 La Niña onset. Bull. Amer. Meteor. Soc., 80, 217-244.

Beltrando, G., and P. Camberlin, 1993: Interannual variability of rainfall in the eastern Horn of Africa and indicators of atmospheric circulation. Int. J. Climatol., 13, 533-546.

Bradley, R. S., H. F. Diaz, G. N. Kiladis, and J. K. Eischeid, 1987: ENSO signal in continental temperature and precipitation records. Nature, 327, 497-501.

Bromwich, D. H., A. N. Rogers, P. Kållberg, R. I. Cullather, J. W. C. White, and K. J. Kreutz, 2000: ECMWF analyses and reanalyses depiction of ENSO signal in Antarctic precipitation. J. Climate, 13, 1406-1420.

Brown, B. G., and R. W. Katz, 1991: Use of statistical methods in the search for teleconnections. Teleconnections Linking Worldwide Climate Anomalies: Scientific Basis and Societal Impact, M. H. Glantz, R. W. Katz, and N. Nicholls, Eds., Cambridge University Press, 371-400.

Bunkers, M. J., J. R. Miller, and A. T. DeGaetano, 1996: An examination of El Niño-La Niña-related precipitation and temperature anomalies across the northern plains. J. Climate, 9, 147-160.

Cane, M. A., and S. E. Zebiak, 1985: A theory for El Niño and the Southern Oscillation. Science, 228, 1085-1087.

- — - and S. C. Dolan, 1986: Experimental forecasts of El Niño. Nature, 321, 827-832.

Corti, S., F. Molteni, and E. Brankovic, 2000: Predictability of snow-depth anomalies over Eurasia and associated circulation patterns. Quart. J. Roy. Meteor. Soc., 126, 241-262.

Davies, J. R., D. P. Rowell, and C. K. Folland, 1997: North Atlantic and European seasonal predictability using an ensemble of multidecadal atmospheric GCM simulations. Int. J. Climatol., 17, 1263-1284.

Eischeid, J. K., H. G. Diaz, R. S. Bradley, and P. D. Jones, 1991: A comprehensive precipitation data set for global land areas. Carbon Dioxide Research Division Tech. Rep. TR051, U.S. Dept. of Energy, $81 \mathrm{pp}$.

Enfield, D. B., 1996: Relationships of inter-American rainfall to tropical Atlantic and Pacific SST variability. Geophys. Res. Lett., 23, 3305-3308.

Farmer, G., 1988: Seasonal forecasting of the Kenya coast Short Rains, 1901-84. J. Climatol., 8, 489-497.

Ferranti, L., and F. Molteni, 1999: Ensemble simulations of Eurasian snow-depth anomalies and their influence on the summer Asian monsoon. Quart. J. Roy. Meteor. Soc., 125, 2597-2610.

Fisher, R. A., 1935: The logic of inductive inference (with discussion). J. Roy. Stat. Soc., 98, 39-82.

_ 1970: Statistical Methods for Research Workers. Oliver and Boyd, 362 pp.

Fontaine, B., S. Janicot, and P. Roucou,1999: Ocean-atmosphere surface variability and its climate impacts in the tropical Atlantic region. Climate Dyn., 15, 451-473.

Fraedrich, K., 1994: An ENSO impact on Europe? A review. Tellus, 46A, 541-552.
Gershunov, A., 1998: ENSO influence on intraseasonal extreme rainfall and temperature frequencies in the contiguous United States: Implications for long-range predictability. J. Climate, 11, 3192-3203.

_ , and T. P. Barnett, 1998: Interdecadal modulation of ENSO teleconnections. Bull. Amer. Meteor. Soc., 79, 2715-2725.

Goddard, L., and N. E. Graham, 1999: The importance of the Indian Ocean for simulating rainfall anomalies over eastern and southern Africa. J. Geophys. Res., 104, 19 099-19 116.

_ - S. J. Mason, N. E. Graham, and W. Thiaw, 1998: Climate surprises of the 1997-98 El Niño. Proc. 23d Annual Climate Diagnostics and Prediction Workshop, Miami, FL, U.S. Department of Commerce, 34-37.

Gong, D. Y., and S. W. Wang, 1999: Impacts of ENSO on rainfall of global land and China. Chin. Sci. Bull., 44, 852-857.

Gray, W. M., and J. D. Sheaffer, 1991: El Niño and QBO influences on tropical cyclone activity. Teleconnections Linking Worldwide Climate Anomalies: Scientific Basis and Societal Impact, M. H. Glantz, R. W. Katz, and N. Nicholls, Eds., Cambridge University Press, 257-284.

Grimm, A. M., S. E. T. Ferraz, and J. Gomes, 1998: Precipitation anomalies in southern Brazil associated with El Niño and La Niña events. J. Climate, 11, 2863-2880.

_ , V. P. Barros, and M. E. Doyle, 2000: Climate variability in southern South America associated with El Niño and La Niña events. J. Climate, 13, 35-58.

Hahn, D., and J. Shukla, 1976: An apparent relationship between Eurasian snow cover and Indian monsoon rainfall. J. Atmos. Sci., 33, 2461-2463.

Halpert, M. S., and C. F. Ropelewski, 1992: Surface temperature patterns associated with the Southern Oscillation. J. Climate, 5, 577-593.

He, Y., and A. G. Barnston, 1996: Long-lead forecasts of seasonal precipitation in the tropical Pacific islands using CCA. J. Climate, 9, 2020-2035.

Higgins, R. W., K. C. Mo, and Y. Yao, 1998: Interannual variability of the U.S. summer precipitation regime with emphasis on the southwestern monsoon. J. Climate, 11, 2582-2606.

Hoerling, M. P., and A. Kumar, 1997: Why do North American climate anomalies differ from one El Niño event to another? Geophys. Res. Lett., 24, 1059-1062.

—_, _ - and M. Zhong, 1997: El Niño, La Niña, and the nonlinearity of their teleconnections. J. Climate, 10, 17691786.

Hulme, M. H., 1994: Validation of large-scale precipitation fields in General Circulation Models. Global Precipitation and Climate Change, M. Desbois and F. Desalmund, Eds., NATO ASI Series, Springer-Verlag, 387-406.

Hutchinson, P., 1992: The Southern Oscillation and prediction of "Der" season rainfall in Somalia. J. Climate, 5, 525-531.

Irwin, J. O., 1935: Tests of significance for differences between percentages based on small numbers. Metron, 12, 83-94.

Janicot, S., A. Harzallah, B. Fontaine, and V. Moron, 1998: West African monsoon dynamics and eastern equatorial Atlantic and Pacific SST anomalies (1970-83). J. Climate, 11, 412-430.

Kadioglu, M., Y. Tulunay, and Y. Borhan, 1999: Variability of Turkish precipitation compared to El Niño events. Geophys. Res. Lett., 26, 1597-1600.

Kane, R. P., 1997: Prediction of droughts in north-east Brazil: Role of ENSO and use of periodicities. Int. J. Climatol., 17, 655-665. 
- 1999a: Some characteristics and precipitation effects of the El Niño of 1997-1998. J. Atmos. Terr. Phys., 61, 1325-1346.

_ 1999 b: Rainfall extremes in some selected parts of Central and South America: ENSO and other relationships reexamined. Int. J. Climatol., 19, 423-455.

Kaplan, A., M. A. Cane, Y. Kushnir, A. Clement, M. Blumenthal, and R. Rajagopalan, 1998: Analyses of global sea surface temperature 1856-1991. J. Geophys. Res., 103, 18 567-18 589.

Katz, R. W., 1988: Use of cross correlations in the search for teleconnections. J. Climatol., 8, 241-253.

— search on teleconnections. Int. J. Climatol., 11, 505-513.

Kawamura, R., 1998: A possible mechanism of the Asian summer monsoon-ENSO coupling. J. Meteor. Soc. Japan, 76, 1009-1027.

Kiladis, G. N., and H. van Loon, 1988: The Southern Oscillation. Part VII: Meteorological anomalies over the Indian and Pacific sectors associated with the extremes of the oscillation. Mon. Wea. Rev., 116, 120-136,.

— , and H. F. Diaz, 1989: Global climate anomalies associated with extremes in the Southern Oscillation. J. Climate, 2, 10691090.

Kruger, A. C., 1999: The influence of the decadal-scale variability of summer rainfall on the impact of El Niño and La Niña events in South Africa. Int. J. Climatol., 19, 59-68.

Kumar, K. K., B. Rajagopalan, and M. A. Cane, 1999: On the weakening relationship between the Indian moonsoon and ENSO. Science, 284, 2156-2159.

Lamb, P. J., and R. A. Peppler, 1992: Further case-studies of tropical Atlantic surface atmospheric and oceanic patterns associated with sub-Saharan drought. J. Climate, 5, 476-488.

Landsea, C. W., and J. A. Knaff, 2000: How much skill was there in forecasting the very strong 1997-98 El Niño. Bull. Amer. Meteor. Soc., 81, 2107-2119.

Latif, M., and Coauthors, 1998: A review of the predictability and prediction of ENSO. J. Geophys. Res., 103, 14 375-14 393.

Lau, K. M., and P. J. Sheu, 1991: Teleconnections in global rainfall anomalies: seasonal to inter-decadal time scales. Teleconnections Linking Worldwide Climate Anomalies: Scientific Basis and Societal Impact, M. H. Glantz, R. W. Katz, and N. Nicholls, Eds., Cambridge University Press, 227-256.

Livezey, R. E., and W. Y. Chen, 1983: Statistical field significance and its determination by Monte Carlo techniques. Mon. Wea. Rev., 111, 46-59.

_- M. Masutani, A. Leetmaa, H. Rui, M. Ji, and A. Kumar, 1997: Teleconnective response of the Pacific-North American region atmosphere to large central equatorial Pacific SST anomalies. J. Climate, 10, 1787-1820.

Lucero, O. A., 1998: Effects of the southern oscillation on the probability for climatic categories of monthly rainfall in a semi-arid region in the southern mid-latitudes. Atmos. Res., 49, 337-348.

Mason, S. J., and G. M. Mimmack, 1992: The use of bootstrap correlation coefficients in climatology. Theor. Appl. Climatol., 45, 229-233.

_, and M. R. Jury, 1997: Climatic variability and change over southern Africa: A reflection on underlying processes. Progr. Phys. Geogr., 21, 23-50.

— of droughts over southern Africa. Drought. Volume 1: A Global Assessment, D. A. Wilhite, Eds., Routledge, 113-134.
— , L. Goddard, N. E. Graham, E. Yulaeva, L. Sun, and P. A. Arkin, 1999: The IRI seasonal climate prediction system and the 1997/98 El Niño event. Bull. Amer. Meteor. Soc., 80, 18531873.

Masutani, M., and A. Leetmaa, 1999: Dynamical mechanisms of the 1995 California floods. J. Climate, 12, 3220-3236.

McCabe, G. J., and M. D. Dettinger, 1999: Decadal variations in the strength of the ENSO teleconnections with precipitation in the western United States. Int. J. Climatol., 19, 1399-1410.

Minnich, R. A., E. F. Vizcaino, and R. J. Dezzani, 2000: The El Niño/Southern Oscillation and precipitation variability in Baja California, Mexico. Atmosfera, 13, 1-20.

Mo, K. C., and R. W. Higgins, 1998: Tropical influences on California precipitation. J. Climate, 11, 412-430.

Montecinos, A., A. Díaz, and P. Aceituno, 2000: Seasonal diagnostic and predictability of rainfall in subtropical South America based on tropical Pacific SST. J. Climate, 13, 746758.

Montroy, D. L., 1997: Linear relation of central and eastern North American precipitation to tropical Pacific sea surface temperature anomalies. J. Climate, 10, 541-558.

_ earities of monthly teleconnections between tropical Pacific sea surface temperature anomalies and central and eastern North American precipitation. J. Climate, 11, 1812-1835.

Moron, V., S. Bigot, and P. Roucou, 1995: Rainfall variability in subequatorial America and Africa and relationships with the main sea-surface temperature modes (1951-1990). Int. J. Climatol., 15, 1297-1322.

Mutai, C. C., M. N. Ward, and A. W. Colman, 1998: Towards the prediction of the East Africa short rains based on sea-surface temperature-atmosphere coupling. Int. J. Climatol., 18, 975-997.

Navarra, A., M. N. Ward, and K. Miyakoda, 1999: Tropical-wide teleconnection and oscillation. I: Teleconnection indices and type I/type II states. Quart. J. Roy. Meteor. Soc., 125, 2909 2935.

Nazemosadat, M. J., and I. Gordery, 2000: On the relationship between ENSO and autumn rainfall in Iran. Int. J. Climatol., 20, 47-61.

Neelin, J. D., D. S. Battisti, A. C. Hirst, F. F. Jin, Y. Wakata, T. Yamagata, and S. E. Zebiak, 1998: ENSO theory. $J$. Geophys. Res., 103, 14 261-14 290.

New, M., M. Hulme, and P. D. Jones, 1999: Representing twentieth century space-time climate variability. Part I: Development of a 1961-90 mean monthly terrestrial climatology. J. Climate, 12, 829-856.

- — — space-time climate variability. Part II: Development of 190196 monthly grids of terrestrial surface climate. J. Climate, 13, 2217-2238.

Nicholls, N., B. Lavery, C. Fredericksen, W. Drosdowsky, and S. Torok, 1996: Recent apparent changes in relationships between the El Niño-Southern Oscillation and Australian rainfall and temperature. Geophys. Res. Lett., 23, 3357-3360.

Nobre, P., and I. F. A. Cavalcanti, 1999: The prediction of drought in the Brazilian Nordeste: Progress and prospects for the future. Drought Volume 1: A Global Assessment, D. A. Wilhite, Ed., Routledge, 68-82.

Palmer, T. N., and D. L. T. Anderson, 1994: The prospects for seasonal forecasting. Quart. J. Roy. Meteor. Soc., 120, 755-793. 
Parthasarathy, B., H. F. Diaz, and J. K. Eischeid, 1988: Predictions of all-India summer monsoon rainfall and the Southern Oscillation. J. Geophys. Res., 93, 5341-5350.

Pittock, A. B., 1984: On the reality, stability, and usefulness of Southern Hemisphere teleconnections. Aust. Meteor. Mag., 32, 75-82.

Power, S., T. Casey, C. K. Folland, A. Colman, and V. Mehta, 1999: Inter-decadal modulation of the impact of ENSO on Australia. Climate Dyn., 15, 319-324.

Price, C., L. Stone, A. Huppert, B. Rajagopalan, and P. Alpert, 1998: A possible link between El Niño and precipitation in Israel. Geophys. Res. Lett., 25, 3963-3966.

Quinn, W. H., D. O. Zopf, K. S. Short, and R. T. W. Kuo Yang, 1978: Historical trends and statistics of the Southern Oscillation, El Niño and Indonesian droughts. Fish. Bull., 76, 663-678.

Ramage, C. S., 1983: Teleconnections and the siege of time. $J$. Climatol., 3, 223-231.

Rocha, A., 1999: Low-frequency variability of seasonal rainfall over the Iberian Peninsula and ENSO. Int. J. Climatol., 19, 889-901.

Rodo, X., E. Baert, and F. A. Comin, 1997: Variations in seasonal rainfall in southern Europe during the present century: Relationships with the North Atlantic oscillation and the El Niño Southern Oscillation. Climate Dyn., 13, 275-284.

Ropelewski, C. F., and M. S. Halpert, 1986: North American precipitation and temperature patterns associated with the El Niño Southern Oscillation (ENSO). Mon. Wea. Rev., 114, 23522362.

$\longrightarrow$, and _ 1987: Global and regional scale precipitation patterns associated with the El Niño Southern Oscillation. Mon. Wea. Rev., 115, 1606-1626.

$\longrightarrow$, and -1989 : Precipitation patterns associated with the high index phase of the Southern Oscillation. J. Climate, 2, 268-284.

- , and - 1996: Quantifying Southern Oscillationprecipitation relationships. J. Climate, 9, 1043-1059.

Schonher, T., and S. E. Nicholson, 1989: The relationship between California rainfall and ENSO events. J. Climate, 2, 1258-1269.

Semazzi, F. H. M., V. Mehta, and Y. C. Sud, 1988: An investigation of the relationship between sub-Saharan rainfall and global sea-surface temperatures. Atmos.-Ocean, 26, 118-138.

Shukla, J., and D. A. Paolina, 1983: The southern oscillation and long range forecasting of the summer monsoon rainfall over India. Mon. Wea. Rev., 111, 1830-1837.

Stockdale, T. N., D. L. T. Anderson, J. O. S. Alves, and M. A. Balmaseda, 1998a: Global seasonal rainfall forecasts using a coupled ocean-atmosphere model. Nature, 392, 370-373.

— A. J. Busalacchi, D. E. Harrison, and R. Seager, 1998b: Ocean modeling for ENSO. J. Geophys. Res., 103, 14 325-14 355.
Stone, R., and A. Auliciems, 1992: SOI phase relationships with rainfall in eastern Australia. Int. J. Climatol., 12, 625-636.

Thiaw, W. M., A. G. Barnston, and V. Kumar, 1999: Predictions of African rainfall on the seasonal timescale. J. Geophys. Res., 104, 31 589-31 597.

Torrence, C., and P. J. Webster, 1999: Interdecadal changes in the ENSO-monsoon system. J. Climate, 12, 2679-2690.

Uvo, C. B., C. A. Repelli, S. E. Zebiak, and Y. Kushir, 1998: The relationships between tropical Pacific and Atlantic SST and northeast Brazil monthly precipitation. J. Climate, 11, 551562.

van Oldenborgh, G. J., G. Burgers, and A. K. Tank, 2000: On the El Niño teleconnection to spring precipitation in Europe. Int. J. Climatol., 20, 565-574.

Vega, A. J., R. V. Rohli, and K. G. Henderson, 1998: The Gulf of Mexico midtropospheric response to El Niño and La Niña forcing. Climate Res., 10, 115-125.

Wagner, J. A., 1987: The global climate of March-May 1987: Moderately strong mature phase of ENSO with highly persistent monthly and seasonal temperature anomalies over the United States. Mon. Wea. Rev., 115, 3166-3187.

Wang, B., R. Wu, and X. Fu, 2000: Pacific-East Asian teleconnection: How does ENSO affect East Asian climate? J. Climate, 13, 1517-1536.

Ward, M. N., 1998: Diagnosis and short-lead time prediction of summer rainfall in tropical North Africa at interannual and multidecadal timescales. J. Climate, 11, 3167-3191.

— the north Nordeste of Brazil using eigenvectors of sea-surface temperatures. Int. J. Climatol., 11, 711-743.

Waylen, P. R., and S. Henworth, 1996: A note on the timing of precipitation variability in Zimbabwe as related to the Southern Oscillation. Int. J. Climatol., 16, 1137-1148.

$\longrightarrow$, C. N. Caviedes, and M. E. Quesada, 1996: Interannual variability of monthly precipitation in Costa Rica. J. Climate, 9, 2606-2613.

Webster, P. J., V. O. Magaña, T. N. Palmer, J. Shukla, R. A. Tomas, M. Yanai, and T. Yasunari, 1998: Monsoons: processes, predictability, and the prospects for prediction. $J$. Geophys. Res., 103, 14 451-14 510.

Wigley, T. M. L., and P. D. Jones, 1987: England and Wales precipitation: A discussion of recent changes in variability and an update to 1985. J. Climatol., 7, 231-246.

Wilks, D. S., 1995: Statistical Methods in the Atmospheric Sciences. Academic Press, 467 pp.

Wu, T., 1993: An accurate computation of the hypergeometric distribution function. ACM Trans. Math. Software, 19, 33-43.

Xavier, T. D. B. S., M. A. F. S. Dias, and A. F. S. Xavier, 1995: Impact of ENSO episodes on the autumn rainfall patterns near Sao Paulo, Brazil. Int. J. Climatol., 15, 571-584.

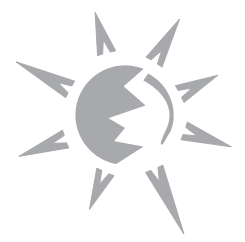

